\title{
Heterobimetallic $\mathrm{Fe}-\mathrm{Pd}$ and $\mathrm{Fe}-\mathrm{Pt} \mathrm{NCN}$ pincer complexes $\left(\mathrm{NCN}=\left[\mathrm{C}_{6} \mathrm{H}_{2}\left(\mathrm{CH}_{2} \mathrm{NMe}_{2}\right)_{2}-2,6\right]^{-}\right)$
}

\author{
Stefan Köcher ${ }^{\text {a }}$, Martin Lutz ${ }^{\mathrm{b}}$, Anthony L. Spek ${ }^{\mathrm{b}, 1}$, Rajendra Prasad ${ }^{\mathrm{c}}$, \\ Gerard P.M. van Klink ${ }^{\mathrm{d}}$, Gerard van Koten ${ }^{\mathrm{d}}$, Heinrich Lang ${ }^{\mathrm{a}, *}$ \\ a Technische Universität Chemnitz, Fakultät für Naturwissenschaften, Institut für Chemie, Lehrstuhl für Anorganische Chemie, Straße der Nationen 62, \\ 09111 Chemnitz, Germany \\ ${ }^{\mathrm{b}}$ Bijvoet Center for Biomolecular Research, Crystal and Structural Chemistry, Utrecht University, Padualaan 8, 3584 CH Utrecht, The Netherlands \\ ${ }^{\mathrm{c}}$ Indian Institute of Technology Roorkee, Roorkee, 247667 Uttaranchal, India \\ d Debye Institute, Organic Chemistry and Catalysis, Utrecht University, Padualaan 8, 3584 CH Utrecht, The Netherlands
}

Received 18 April 2006; accepted 2 May 2006

Available online 25 July 2006

\begin{abstract}
The meta-diaminoaryl ferrocenes $\mathrm{Fc}-\mathrm{NCN}-\mathrm{H} \quad$ (3) and $\mathrm{Fc}-\mathrm{C} \equiv \mathrm{C}-\mathrm{NCN}-\mathrm{H} \quad(\mathbf{5}) \quad\left(\mathrm{Fc}=\left(\eta^{5}-\mathrm{C}_{5} \mathrm{H}_{5}\right)\left(\eta^{5}-\mathrm{C}_{5} \mathrm{H}_{4}\right) \mathrm{Fe}, \quad \mathrm{NCN}-\mathrm{H}=\right.$ $\left.\mathrm{C}_{6} \mathrm{H}_{3}\left(\mathrm{CH}_{2} \mathrm{NMe}_{2}\right)_{2}-3,5\right)$ can be used as precursors in the preparation of heterobimetallic transition metal complexes of structural type $\mathrm{Fc}-\mathrm{NCN}-\mathrm{MX}\left(\mathrm{NCN}=\left[\mathrm{C}_{6} \mathrm{H}_{2}\left(\mathrm{CH}_{2} \mathrm{NMe}_{2}\right)_{2}-2,6\right]^{-} ; \mathrm{MX}=\mathrm{PdCl}(7), \mathrm{PtCl}(8), \mathrm{PtI}(9)\right)$ and $\mathrm{Fc}-\mathrm{C} \equiv \mathrm{C}-\mathrm{NCN}-\mathrm{MX}(\mathrm{MX}=\mathrm{PdCl}(11), \mathrm{PdI}$ (12), $\mathrm{PtCl}(13))$, respectively. They are accessible by applying different synthesis procedures, including oxidative addition and metallation-transmetallation processes.

Cyclovoltammetric studies show that the ferrocene moieties in 3, 5, 7-9 and 11-13 can reversibly be oxidised. The potential of the $\mathrm{Fe}(\mathrm{II}) / \mathrm{Fe}(\mathrm{III})$ redox couple decreases with increasing electron density at the NCN pincer unit. The use of $\mathbf{8}$ as a possible (electro)chemical sensor in the detection of $\mathrm{SO}_{2}$ is discussed as well.

The solid-state structures of $\mathbf{8}$ and $\mathbf{1 3}$ are reported. The crystals of $\mathbf{8}$ contain two molecules of $\mathbf{8}$ in the asymmetric unit. The plane of the $\mathrm{C}_{6} \mathrm{H}_{2}$ moiety is with $27.2(3)^{\circ}$ and $38.2(3)^{\circ}$ tilted towards the $\mathrm{C}_{5} \mathrm{H}_{4}$ entity, while in $\mathbf{1 3}$ an angle of $45.9(3)^{\circ}$ can be found. The $\mathrm{d}^{8}$-electron configured platinum atoms possess a somewhat distorted square-planar surrounding, setup by two $\mathrm{Me}_{2} \mathrm{NCH}_{2}$ ortho-substituents, the $\mathrm{NCN} \mathrm{C}_{\text {ipso }}$ carbon atom and the chloride ligand.
\end{abstract}

(C) 2006 Elsevier B.V. All rights reserved.

Keywords: NCN pincer; Ferrocene; Palladium; Platinum; Halide; Sensor; Cyclicvoltammetry; X-ray crystal structure

\section{Introduction}

Over the last years, the manifold coordination chemistry of diphosphino- and disulfido-aryl anions and the related diaminoaryl pincers $\mathrm{NCN} \quad\left(\mathrm{NCN}=\left[\mathrm{C}_{6} \mathrm{H}_{3}-\right.\right.$ $\left.\left.\left(\mathrm{CH}_{2} \mathrm{NMe}_{2}\right)_{2}-2,6\right]^{-}\right)$towards different transition metal ions has been intensively investigated [1,2]. In this accessible transition metal pincer complexes, stable metal-carbon

\footnotetext{
* Corresponding author. Tel.: +493715311673.

E-mail address: heinrich.lang@chemie.tu-chemnitz.de (H. Lang).

${ }^{1}$ Author, to whom correspondence pertaining crystal structure analysis should be addressed.
}

$\sigma$-bonds are present, due to the chelating effect of, i.e. the two $\mathrm{Me}_{2} \mathrm{NCH}_{2}$ ortho-substituents [3]. The synthesis of para-functionalised $\mathrm{Y}-\mathrm{NCN}-\mathrm{MX}$ complexes $(\mathrm{M}=\mathrm{Ni}$, $\mathrm{Pd}, \mathrm{Pt} ; \mathrm{X}=$ halide; $\mathrm{Y}=$ alkynyl, halide,...) opens the possibility to prepare larger molecules with specific physical and chemical properties [4]. Such species are of particular interest, since they can be used as building blocks in, for example, the synthesis of one-dimensional molecular wires with electronic conduction along a linear $\pi$-conjugated organometallic chain [5]. They also provide an entry into liquid crystalline materials [6], homogeneous catalysis or molecular electronics, i.e. optical and physical sensors [7]. Among them, redox-active organic and/or 
organometallic species with reversibly switchable electron density and electronic properties are attractive building blocks. The one-electron reservoir ferrocene is, due to its robustness, a most promising unit to be incorporated in such multimetallic assemblies.

The oxidation of ferrocene-based compounds is possible by using electrochemical methods such as cyclicvoltammetry to determine the $\mathrm{Fe}^{2+} / \mathrm{Fe}^{3+}$ redox potential and with that the electron density at the ferrocene moiety. This gives rise to the possibility to use such systems as sensory materials which can electrochemically be read out.

We report here on the synthesis of NCN pincer-substituted ferrocenes of type $\mathrm{Fc}-\mathrm{NCN}-\mathrm{H}$ and $\mathrm{Fc}-\mathrm{C} \equiv \mathrm{C}-$ $\mathrm{NCN}-\mathrm{H}\left(\mathrm{NCN}-\mathrm{H}=\mathrm{C}_{6} \mathrm{H}_{3}\left(\mathrm{CH}_{2} \mathrm{NMe}_{2}\right)_{2}-3,5\right)$ and on their subsequent metallation to heterobimetallic $\mathrm{Fc}-\mathrm{NCN}-\mathrm{MX}$ and $\mathrm{Fc}-\mathrm{C} \equiv \mathrm{C}-\mathrm{NCN}-\mathrm{MX}$ complexes $\left(\mathrm{NCN}=\left[\mathrm{C}_{6} \mathrm{H}_{2}\left(\mathrm{CH}_{2}-\right.\right.\right.$ $\left.\left.\mathrm{NMe}_{2}\right)_{2}-2,6\right]^{-} ; \mathrm{M}=\mathrm{Pd}$, Pt; $\mathrm{X}=\mathrm{Cl}$, I), respectively. Their electrochemical behaviour and reversible absorption ability towards $\mathrm{SO}_{2}$ is discussed as well.

\section{Results and discussion}

\subsection{Synthesis and spectroscopy}

Carbon-carbon cross-coupling catalysed by transition metals can successfully be used to prepare rigid-rod structured $\pi$-conjugated organic and organometallic NCN pincer-functionalised ferrocenes $[8,9]$.

Treatment of $\mathrm{Fc}-\mathrm{B}(\mathrm{OH})_{2} \quad(\mathbf{1}) \quad\left(\mathrm{Fc}=\left(\eta^{5}-\mathrm{C}_{5} \mathrm{H}_{5}\right)-\right.$ $\left.\left(\eta^{5}-\mathrm{C}_{5} \mathrm{H}_{4}\right) \mathrm{Fe}\right)$ with I-1- $\mathrm{C}_{6} \mathrm{H}_{3}\left(\mathrm{CH}_{2} \mathrm{NMe}_{2}\right)_{2}-3,5$ (2) following the Suzuki cross-coupling protocol [8e] in presence of catalytic amounts of $\left[(\mathrm{dppf}) \mathrm{PdCl}_{2}\right] \quad\left(\mathrm{dppf}=1,1^{\prime}\right.$-bis(diphenylphosphino)ferrocene) gives $\mathrm{Fc}-\mathrm{NCN}-\mathrm{H}$ $\left(\mathrm{NCN}-\mathrm{H}=\mathrm{C}_{6} \mathrm{H}_{3}-\left(\mathrm{CH}_{2} \mathrm{NMe}_{2}\right)_{2}-3,5\right)$ (Eq. (1)) which after appropriate work-up, can be isolated as a red oil in $27 \%$ yield.

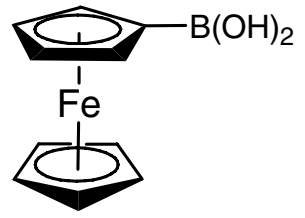

1

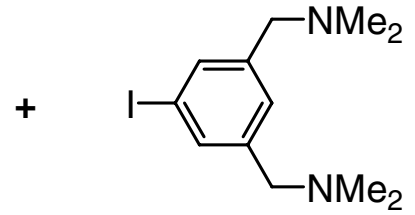

2

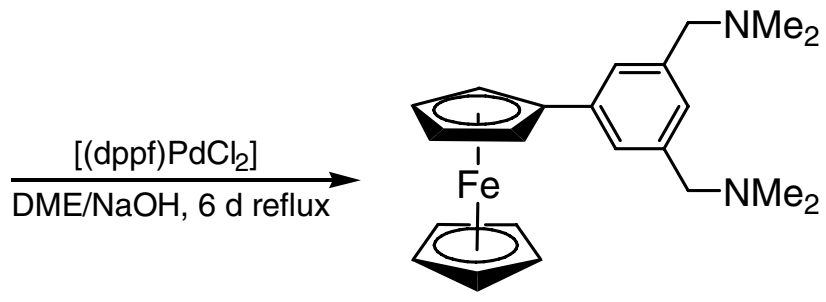

In 3 the NCN pincer moiety is connected to the ferrocene core via a single carbon-carbon bond. This might lead to repulsive interactions between the ortho-hydrogen atoms of the $\mathrm{C}_{5} \mathrm{H}_{4}$ and $\mathrm{C}_{6} \mathrm{H}_{3}$ rings and hence, these two planes will be twisted towards each other. This may prevent an effective electronic communication between the iron atom and the metallated NCN pincer unit. Thus, the insertion of a suitable $\pi$-conjugated $-\mathrm{C} \equiv \mathrm{C}$ - or $-\mathrm{C}=\mathrm{C}$ - spacer is a promising alternative, although the electronically interacting parts will be more separated from each other. Therefore, $\mathrm{Fc}-\mathrm{C} \equiv \mathrm{C}-\mathrm{NCN}-\mathrm{H} \quad(\mathbf{5})$ was prepared in a Sonogashira reaction $[8 \mathrm{~d}]$ by reacting $\mathrm{Fc}-\mathrm{C} \equiv \mathrm{CH}$ (4) with 2 in the presence of catalytic amounts of $\left[\left(\mathrm{Ph}_{3} \mathrm{P}\right)_{2} \mathrm{PdCl}_{2}\right] /$ $[\mathrm{CuI}]$ in diisopropyl amine as solvent (Eq. (2)). After appropriate work-up, 5 could be isolated as an orangered oil in $75 \%$ yield.

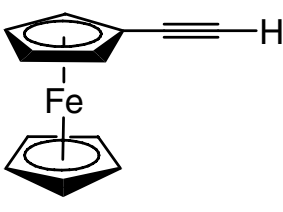

4

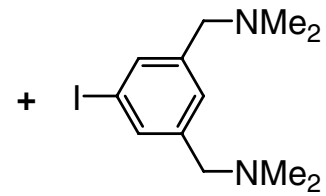

2

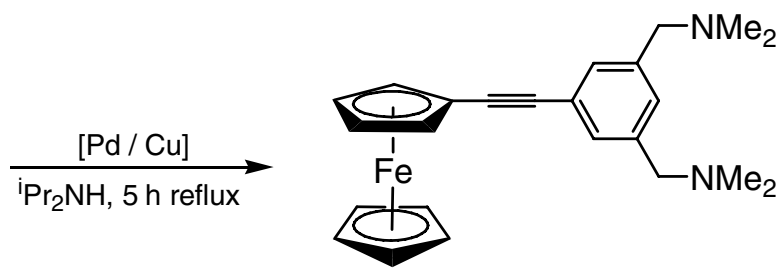

5

Compounds $\mathbf{3}$ and $\mathbf{5}$ are soluble in common organic solvents, such as $n$-hexane, toluene, diethyl ether and dichloromethane.

Treatment of $n$-hexane solutions containing 3 or 5 with ${ }^{n} \mathrm{BuLi}$ gave $\mathbf{L i}-\mathbf{3}$ and $\mathbf{L i}-\mathbf{5}$ which further react with an excess of iodine to produce the iodo-functionalised sandwich complexes $\mathrm{Fc}-\mathrm{NCN}-\mathrm{I}(\mathbf{6})$ and $\mathrm{Fc}-\mathrm{C} \equiv \mathrm{C}-\mathrm{NCN}-\mathrm{I}(\mathbf{1 0})$ as orange oils in $82 \%$ and $80 \%$ yield, respectively (Schemes 1 and 2).

On reacting either 6 with equimolar amounts of $\left[\mathrm{Pt}(\mathrm{tol})_{2}\left(\mathrm{SEt}_{2}\right)\right]_{2} \quad$ (tol $=4$-tolyl) in refluxing toluene for 5 min, or $\mathbf{1 0}$ with stoichiometric amounts of the Pd source $\left[\mathrm{Pd}_{2}(\mathrm{dba})_{3} \cdot \mathrm{CHCl}_{3}\right](\mathrm{dba}=$ dibenzylideneacetone $)$ in benzene at $25^{\circ} \mathrm{C}$, an oxidative addition of the $\mathrm{C}-\mathrm{I}$ bond in $\mathbf{6}$ and 10 to $\mathrm{M}(\mathrm{M}=\mathrm{Pd}, \mathrm{Pt})$ occurs. After appropriate work-up, the respective orange coloured heterobimetallic complexes $\mathrm{Fe}-\mathrm{NCN}-\mathrm{PtI}$ (9) and $\mathrm{Fc}-\mathrm{C} \equiv \mathrm{C}-\mathrm{NCN}-\mathrm{PdI}$ (12) can be isolated in $71 \%$ and $73 \%$ yield, respectively (Schemes 1 and 2).

A possibility to synthesise $7, \mathbf{8 , 1 1}$ and $\mathbf{1 3}$ is given by a two-step metallation-transmetallation procedure: lithiation of $\mathbf{3}$ and $\mathbf{5}$ by the addition of ${ }^{n} \mathrm{BuLi}$ (vide supra) and subsequent treatment of $\mathbf{L i - 3}$ and $\mathbf{~ i i - 5 ~ w i t h ~}\left[\left(\mathrm{Et}_{2} \mathrm{~S}\right)_{2} \mathrm{PdCl}_{2}\right]$ or 


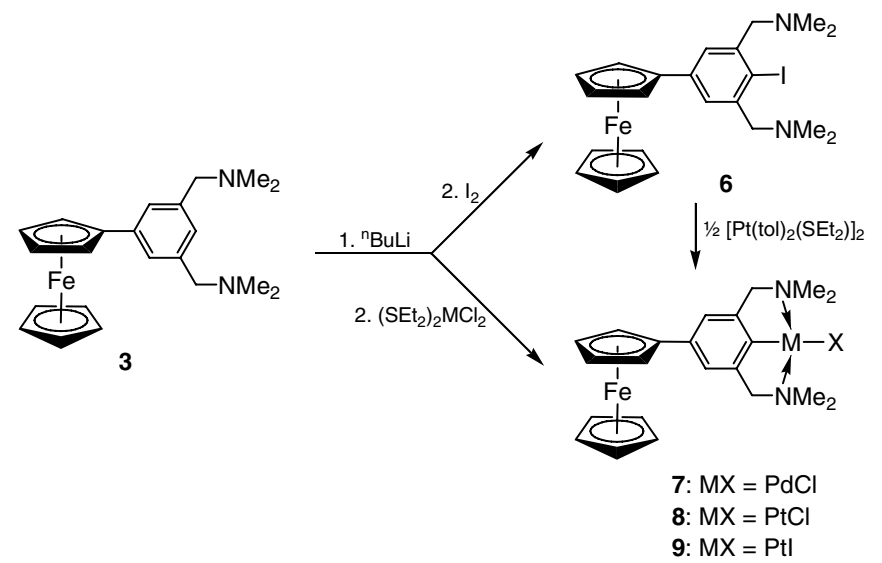

Scheme 1. Synthesis of 6-9.

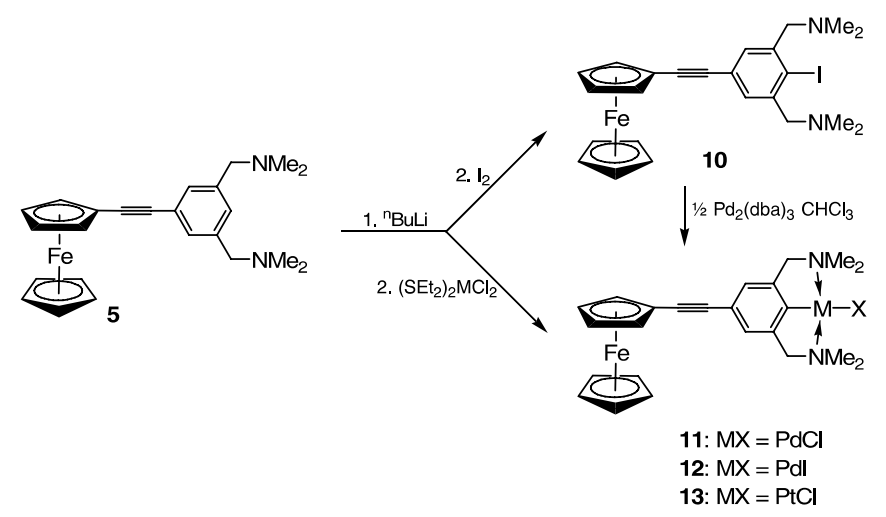

Scheme 2. Synthesis of 10-13.

$\left[\left(\mathrm{Et}_{2} \mathrm{~S}\right)_{2} \mathrm{PtCl}_{2}\right]$ in a 1:1 molar ratio produces heterobimetallic $\mathrm{Fc}-\mathrm{NCN}-\mathrm{MCl}(7: \mathrm{M}=\mathrm{Pd} ; \mathbf{8}: \mathrm{M}=\mathrm{Pt})$ or $\mathrm{Fc}-\mathrm{C} \equiv \mathrm{C}-$ $\mathrm{NCN}-\mathrm{MCl}(11: \mathrm{M}=\mathrm{Pd}$; 13: $\mathrm{M}=\mathrm{Pt})$ in yields between $30 \%$ and $75 \%$ (Schemes 1 and 2). Nevertheless, the presence of a $\mathrm{C} \equiv \mathrm{C}$ triple bond as given in $\mathbf{1 1}$ and $\mathbf{1 3}$ decreases the yield of these compounds significantly. A similar trend was found for NCN pincer-functionalised ferrocenes with two $\mathrm{C} \equiv \mathrm{C}$ moieties, where the metallation-transmetallation procedure failed $[9,10]$. In comparison, the iodine-oxidative addition route (synthesis of 12) doubles the yield (58\%), when compared with the lithium-transmetallation protocol (11: 29\%).

The ${ }^{1} \mathrm{H}$ NMR spectra of $\mathbf{3}, \mathbf{5}, \mathbf{6}$ and $\mathbf{1 0}$ show the expected resonance signals typical for non-metallated $\mathrm{NCN}$-pincer complexes [2,3]. The $\mathrm{Me}_{2} \mathrm{~N}$ and $\mathrm{CH}_{2}$ protons appear as singlets at 2.26 and 3.43 ppm for 3 and 2.23 and $3.37 \mathrm{ppm}$ for $\mathbf{5}$. The appropriate resonances for $\mathbf{6}$ and $\mathbf{1 0}$ are observed at 2.35 and $3.54 \mathrm{ppm}$ (6) and 2.34 and $3.51 \mathrm{ppm}(\mathbf{1 0})$. Coordination of the ortho- $\mathrm{Me}_{2} \mathrm{NCH}_{2}$ substituents to palladium $(7,11$ and 12$)$ or platinum $(\mathbf{8}, 9$ and 13) results in a significant low-field shift of the $\mathrm{Me}_{2} \mathrm{~N}$ (2.9-3.2 ppm) and $\mathrm{CH}_{2}$ (ca. $4.0 \mathrm{ppm}$ ) protons. The signals for the $\mathrm{C}_{6} \mathrm{H}_{2}$ entity also confirm the binding of this group to Pd and Pt. Thus, due to the increased electron density at the benzene ring a high-field shift from 7.313 or $7.33 \mathrm{ppm} 5$ to, for example, $6.90 \mathrm{ppm}$ for $\mathbf{7}$ and $\mathbf{1 1}$ is observed (Section
3). In addition, the FePt complexes $\mathbf{8 , 9}$ and $\mathbf{1 3}$ show typical ${ }^{195} \mathrm{Pt}$ satellites with coupling constants of $36-38 \mathrm{~Hz}$ $\left({ }^{3} J_{\mathrm{PtH}(\mathrm{Me})}\right)$ and ca. $46 \mathrm{~Hz}\left({ }^{3} \mathrm{~J}_{\mathrm{PtH}\left(\mathrm{CH}_{2}\right)}\right)$.

In the ${ }^{13} \mathrm{C}\left\{{ }^{1} \mathrm{H}\right\}$ NMR spectra of 7-9 and 11-13 the downfield shift of the $\mathrm{CH}_{2}$ and $\mathrm{NMe}_{2}$ carbon atoms upon complexation to the group-10 transition metals is observed as well (i.e. 3: 64.4, $45.4 \mathrm{ppm}$; 9: 76.8, $56.3 \mathrm{ppm}$ ). The ferrocene ipso-carbon atoms for 3 and 6-9, where the $\mathrm{C}_{6} \mathrm{H}_{2}$ group is directly bonded to the cyclopentadienyl ring, appears between 84 and 87 ppm. For 5 and 10-13 the presence of a $\mathrm{C} \equiv \mathrm{C}$ spacer unit between the sandwich and the $\mathrm{NCN}$ pincer moieties shifts the resonance signal of this carbon atom to ca. $65 \mathrm{ppm}$.

All other resonances for the ferrocene entity in $\mathbf{3}$ and $\mathbf{5}$ 13 in both the ${ }^{1} \mathrm{H}$ and ${ }^{13} \mathrm{C}\left\{{ }^{1} \mathrm{H}\right\}$ NMR spectra are not significantly influenced by the differently substituted NCN units and appear in the region typical for ferrocene-based complexes.

The $\mathrm{C} \equiv \mathrm{C}$ stretching frequencies in $\mathbf{5}$ and $\mathbf{1 0}-\mathbf{1 3}$ are not affected by the introduction of iodine, palladium or platinum and are found at ca. $2210 \mathrm{~cm}^{-1}$ in the IR spectra of these species.

\subsection{Electrochemical studies}

Cyclovoltammetric studies were carried out for 2, 3, 7 and 8 , in acetonitrile and for 5, 8 and 11-13 in tetrahydrofuran solutions. As examples, the cyclic voltammograms of $\mathbf{2}$ and 7 are depicted in Figs. 1 and 2, respectively.

The cyclicvoltammogram of $\mathbf{2}$ shows an irreversible oxidation at $+0.76 \mathrm{~V}$, which also has been found at similar potentials for complexes $\mathbf{3}, \mathbf{5}, \mathbf{7}, \mathbf{8}$ and 11-13 (Table 1). It most likely arises from the oxidation of the NCN pincer unit $[9,11]$. An analogous behaviour has been reported for benzyl amine [12]. The second wave at $+2.13 \mathrm{~V}$ can be assigned to the $\mathrm{I}^{-} / \mathrm{I}_{2}$ oxidation.

The redox potentials of monometallic $\mathbf{3}$ and $\mathbf{5}$ are, when compared to the $\mathrm{Cp}_{2} \mathrm{Fe} / \mathrm{Cp}_{2} \mathrm{Fe}^{+}$redox-couple $\left(\mathrm{Cp}_{2} \mathrm{Fe}=\right.$ $\left.\left(\eta^{5}-\mathrm{C}_{5} \mathrm{H}_{5}\right)_{2} \mathrm{Fe}\right)$, shifted to a somewhat more positive value (Table 1). This change can be explained by the presence of electron withdrawing groups (the NCN pincer and the $\mathrm{C} \equiv \mathrm{C}$ moieties) in $\mathbf{3}$ and $\mathbf{5}$ compared to ferrocene, taken as standard [13].

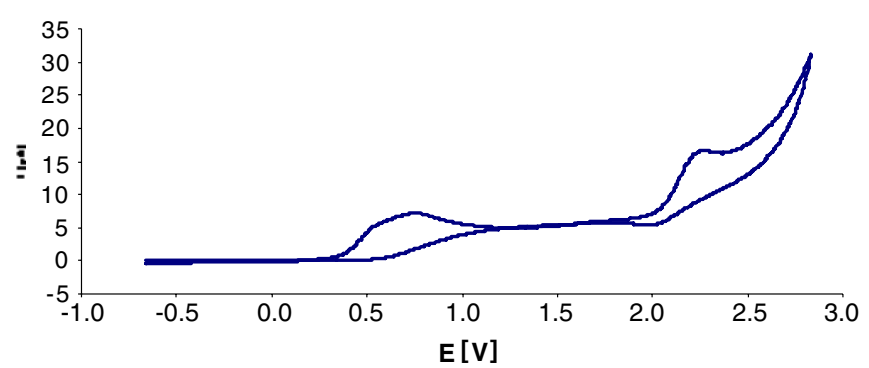

Fig. 1. Cyclic voltammogram of $\mathbf{2}$ in acetonitrile in the presence of $[n$ $\left.\mathrm{Bu}_{4} \mathrm{~N}\right]\left[\mathrm{PF}_{6}\right]\left(c=0.10 \mathrm{M}, 25^{\circ} \mathrm{C}\right.$, argon, scan rate $\left.=200 \mathrm{mV} \mathrm{s}^{-1}\right)$. Potentials are referenced to the $\mathrm{Cp}_{2} \mathrm{Fe} / \mathrm{Cp}_{2} \mathrm{Fe}^{+}$redox couple as internal standard $\left(\mathrm{Cp}_{2} \mathrm{Fe}=\left(\eta^{5}-\mathrm{C}_{5} \mathrm{H}_{5}\right)_{2} \mathrm{Fe}, E_{1 / 2}=0.00 \mathrm{~V}\right)$. 


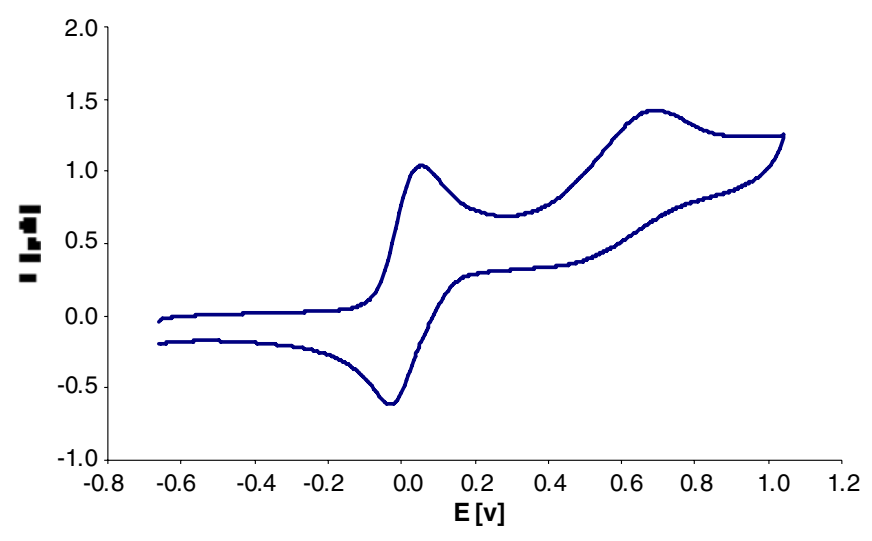

Fig. 2. Cyclic voltammogram of 7 in acetonitrile in the presence of $[n$ $\left.\mathrm{Bu}_{4} \mathrm{~N}\right]\left[\mathrm{PF}_{6}\right]\left(c=0.10 \mathrm{M}, 25^{\circ} \mathrm{C}\right.$, argon, scan rate $\left.=200 \mathrm{mV} \mathrm{s}{ }^{-1}\right)$. Potentials are referenced to the $\mathrm{Cp}_{2} \mathrm{Fe} / \mathrm{Cp}_{2} \mathrm{Fe}^{+}$redox couple as internal standard $\left(\mathrm{Cp}_{2} \mathrm{Fe}=\left(\eta^{5}-\mathrm{C}_{5} \mathrm{H}_{5}\right)_{2} \mathrm{Fe}, E_{1 / 2}=0.00 \mathrm{~V}\right)$.

Table 1

Electrochemical data of $2,3,5,7,8$ and $11-13^{\text {a }}$

\begin{tabular}{lccl}
\hline Compound & $E_{1 / 2}(\mathrm{~V})$ & $\Delta E_{\mathrm{p}}(\mathrm{mV})$ & $E_{\text {ox }}(\mathrm{V})$ \\
\hline $\mathrm{I}-\mathrm{NCNH}(\mathbf{2})^{\mathrm{b}}$ & & & $+0.76,+2.13$ \\
$\mathrm{CpFe}\left(\mathrm{C}_{5} \mathrm{H}_{4} \mathrm{NCNH}\right)(\mathbf{3})^{\mathrm{b}}$ & +0.02 & 80 & +0.72 \\
$\mathrm{CpFe}\left(\mathrm{C}_{5} \mathrm{H}_{4} \mathrm{C}_{2} \mathrm{NCNH}\right)(\mathbf{5})^{\mathrm{c}}$ & +0.10 & 192 & +0.83 \\
$\mathrm{CpFe}\left(\mathrm{C}_{5} \mathrm{H}_{4} \mathrm{NCNPdCl}\right)(\mathbf{7})^{\mathrm{b}}$ & +0.01 & 85 & +0.70 \\
$\mathrm{CpFe}\left(\mathrm{C}_{5} \mathrm{H}_{4} \mathrm{NCNPtCl}\right)(\mathbf{8})^{\mathrm{b}}$ & -0.02 & 70 & +0.68 \\
$\mathrm{CpFe}\left(\mathrm{C}_{5} \mathrm{H}_{4} \mathrm{NCNPtCl}\right)(\mathbf{8})^{\mathrm{c}}$ & -0.05 & 146 & +0.69 \\
$\mathrm{CpFe}\left(\mathrm{C}_{5} \mathrm{H}_{4} \mathrm{C}_{2} \mathrm{NCNPdCl}\right)(\mathbf{1 1})^{\mathrm{c}}$ & +0.08 & 150 & $\mathrm{~d}$ \\
$\mathrm{CpFe}\left(\mathrm{C}_{5} \mathrm{H}_{4} \mathrm{C}_{2} \mathrm{NCNPdI}\right)(\mathbf{1 2})^{\mathrm{c}}$ & +0.06 & 105 & +0.76 \\
$\mathrm{CpFe}\left(\mathrm{C}_{5} \mathrm{H}_{4} \mathrm{C}_{2} \mathrm{NCNPtCl}\right)(\mathbf{1 3})^{\mathrm{c}}$ & -0.03 & 133 & +0.73 \\
\hline
\end{tabular}

${ }^{\text {a }} E_{1 / 2}$ is the potential of the $\mathrm{Fe}^{2+} / \mathrm{Fe}^{3+}$ redox couple, $\Delta E_{\mathrm{p}}$ is the peak-topeak separation between the reduction and oxidation wave maxima, $E_{\mathrm{ox}}$ is the potential of the irreversible oxidation.

${ }^{\mathrm{b}}$ In acetonitrile.

${ }^{\mathrm{c}}$ In tetrahydrofuran.

d Broad oxidation wave which could not be assigned, due to the electrochemical window of the solvent used.

The NCN complexation to either palladium or platinum in 7, 8 and 11-13 leads to a small shift of the $\mathrm{Fe}^{2+} / \mathrm{Fe}^{3+}$ potentials to negative values (Table 1). For example, the cyclicvoltammogram of 7 reveals the ferrocene-based wave at $+0.01 \mathrm{~V}$, showing a small influence of the presence of the palladium(II) ion on the redox potential of the iron atom. As compared with $\mathbf{3}$, a somewhat more pronounced shift $(-40 \mathrm{mV})$ for 8 is found, where a platinum(II) ion is present. A similar dependence of the ferrocene redox couple towards different metal ions was found for bis-NCN pincer-substituted ferrocenes [9]. This confirms that the Fe(II) ion is easier to oxidise, which is most likely caused by the ortho-metallation of the NCN pincer moiety (neutral versus anionic NCN; Pd(II), Pt(II)). For 11-13, where the ferrocene and the pincer entities are connected by an acetylenic unit, an analogous dependence of the ferrocene redox-couple towards the presence of either $\mathrm{Pd}(\mathrm{II})$ or $\mathrm{Pt}(\mathrm{II})$ is observed (Table 1). The degree of interaction is thereof similar for aryl-ferrocenes with a slightly distorted overlap of the $\pi$-orbitals. This distortion overlap can be explained by on the one hand the repulsive interaction of the ortho- hydrogen atoms and on the other hand by the extended distance between the interacting entities by the $\mathrm{C} \equiv \mathrm{C}$ triple bond.

The influence of the $\mathrm{Fe}(\mathrm{II}) / \mathrm{Fe}(\mathrm{III})$ redox couple towards the presence of either palladium or platinum can also be used to monitor modifications in the electron density at the NCN building block by cyclicvoltammetry. It is known that platinum-NCN pincer complexes possess the ability to reversibly bind $\mathrm{SO}_{2}$ [14]. For example, colourless $\mathrm{HO}-$ $\mathrm{NCN}-\mathrm{PtCl}$ absorbs gaseous $\mathrm{SO}_{2}$ to form orange $\mathrm{HO}-$ $\mathrm{NCN}-\mathrm{Pt}(\mathrm{Cl})\left(\mathrm{SO}_{2}\right)$. This colour change is combined with a change of the electron density at the NCN pincer unit [14]. With this in mind, we treated a tetrahydrofuran solution containing 8 with $\mathrm{SO}_{2}$ directly in the $\mathrm{CV}$ cell (Eq. (3)).
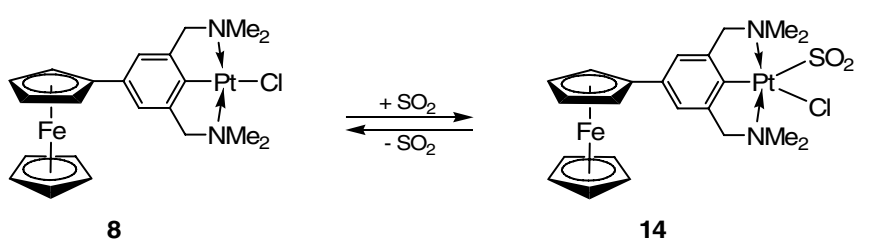

The potential for the $\mathrm{Fe}^{2+} / \mathrm{Fe}^{3+}$ couple for 8 is found at $-0.05 \mathrm{~V}$. Upon bubbling $\mathrm{SO}_{2}$ through this solution this wave is shifted by $20 \mathrm{mV}$ to $-0.03 \mathrm{~V}$ upon formation of $\mathrm{Fc}-\mathrm{NCN}-\mathrm{Pt}(\mathrm{Cl})\left(\mathrm{SO}_{2}\right)(\mathbf{1 4})$. Although the shift is relative small we address the change to the presence of coordinated $\mathrm{SO}_{2}$, since the measurements were performed directly after each other. This finding indicates that the iron centre becomes somewhat more difficult to oxidise, which can explained by a reduced electron density at $\mathbf{1 4}$, when compared with $\mathbf{8}$, due to the $\eta^{1}-\mathrm{S}$ coordination of $\mathrm{SO}_{2}$ to platinum (via interaction of the filled $\mathrm{Pt}-\mathrm{d}_{\mathrm{z}^{2}}$ orbital with the empty $\sigma^{*}$ of $\mathrm{SO}_{2}$ ). This denotes that these heterobimetallic ferrocene-platinum complexes may be used as chemical sensors for $\mathrm{SO}_{2}$. We are currently investigating this topic in further detail.

\subsection{Solid state structures of $\mathbf{8}$ and $\mathbf{1 3}$}

Single crystals of $\mathbf{8}$ and $\mathbf{1 3}$ suitable for X-ray structure analysis could be obtained by slow evaporation of a solution of either $\mathbf{8}$ or $\mathbf{1 3}$ in a dichloromethane-acetone mixture (ratio 20:1) at $-30{ }^{\circ} \mathrm{C}$. The molecular structures of $\mathbf{8}$ and $\mathbf{1 3}$ are shown in Figs. 3 and 4. Geometric details are listed in Table 2 and the experimental crystal data are summarised in Section 3.

Complexes 8 and 13 both crystallise in the monoclinic space group $\mathrm{P} 2{ }_{1} / \mathrm{c}$. The main molecular features of $\mathbf{8}$ and 13 resemble the structural data, characteristic for ferrocene and NCN pincer complexes $[2,15]$. The asymmetric unit of crystals of $\mathbf{8}$ contains two molecules of $\mathbf{8}$, having similar bond distances and bond angles. Therefore, only the data for the residue depicted in Fig. 3 is discussed. As characteristic for other ferrocene complexes the Fe1-D1 and Fe1D2 separations $(\mathrm{D} 1, \mathrm{D} 2=$ centroids of the cyclopentadie- 


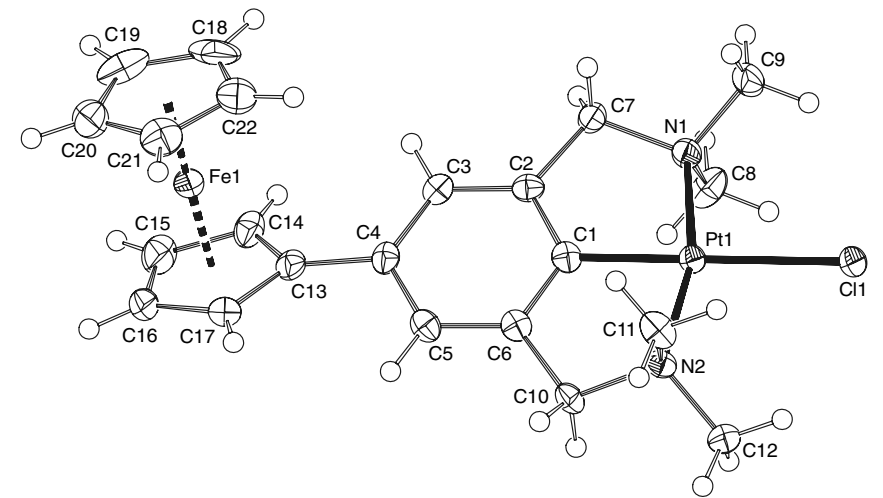

Fig. 3. Displacement ellipsoid plot of the molecular structure of $\mathbf{8}$ in the crystal, drawn at the $50 \%$ probability level. The second independent molecule is omitted for clarity.

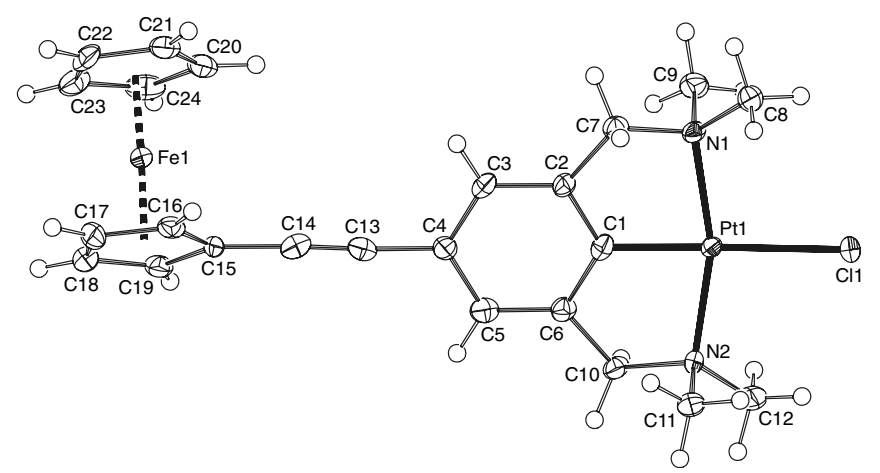

Fig. 4. Displacement ellipsoid plot of the molecular structure of $\mathbf{1 3}$ in the crystal, drawn at the $50 \%$ probability level.

nyl ligands $\mathrm{C}_{5} \mathrm{H}_{4}$ and $\mathrm{C}_{5} \mathrm{H}_{5}$, respectively) are found with $1.641(2)$ and 1.639(3) $\AA$ for 8 and 1.634(3) $\AA$ for 13 [15]. The two cyclopentadienyl ligands are thereby rotated by $-12.2(4)^{\circ} \mathbf{8}$ or $2.5(5)^{\circ} \mathbf{1 3}$ with respect to each other, which verifies an almost eclipsed conformation. The metals Pt1 (8 and 13) adopt a distorted square-planar geometry set-up by
C1, N1, N2 and Cl1 (Figs. 3 and 4). The C1-Pt1-Cl1 bond angles are with $177.57(11)^{\circ} \mathbf{8}$ and $178.91(19)^{\circ} \mathbf{1 3}$ almost linear, whereas the N1-Pt1-N2 angles with $164.65(12)^{\circ} 8$ and $163.09(19)^{\circ} 13$ deviate from linearity. The coordination plane around $\mathrm{Pt} 1$ is almost coplanar with the plane of the $\mathrm{C}_{6} \mathrm{H}_{2}$ ring $\left(8: 8.9^{\circ}, 13: 12.7^{\circ}\right)$. As expected, the $\mathrm{C} \equiv \mathrm{C}$ functionality in $\mathbf{1 3}$ is linear with angels of $177.0(7)^{\circ}(\mathrm{C} 4$ C13-C14) and $177.3(7)^{\circ}(\mathrm{C} 13-\mathrm{C} 14-\mathrm{C} 15)$, respectively.

A further noticeable feature of $\mathbf{8}$ and $\mathbf{1 3}$ is the angle of the planes between the $\mathrm{C}_{6} \mathrm{H}_{2}$ unit and the $\eta^{5}$-coordinated $\mathrm{C}_{5} \mathrm{H}_{4}$ rings. For 8 tilting angles of $27.2(3)^{\circ}$ and $38.2(3)^{\circ}$ and for 13 a value of $45.9(3)^{\circ}$ are found. This orientation averts an optimal overlap between the $\pi$-orbitals of the cyclopentadienyl and NCN-PtCl pincer fragments [16]. However, the interplannar angle seems mainly to depend on crystal packing effects, since for $\mathbf{8}$ two different angels were found and for 13, with less repulsive interactions between the ortho-hydrogen atoms of the $\mathrm{C}_{5} \mathrm{H}_{4}$ and $\mathrm{C}_{6} \mathrm{H}_{2}$ rings, due to the $\mathrm{C} \equiv \mathrm{C}$ spacer, a lager value has been observed.

\section{Experimental part}

\subsection{General methods}

All reactions were carried out under an atmosphere of purified nitrogen using standard Schlenk techniques. Tetrahydrofuran, diethyl ether, benzene, toluene and $n$-hexane were purified by distillation from sodium/benzophenone ketyl. ${ }^{i} \mathrm{Pr}_{2} \mathrm{NH}$ was dried by distillation from $\mathrm{KOH}$. Infrared spectra were recorded with a Perkin-Elmer FT-IR 1000 spectrometer. NMR spectra were recorded with a Bruker Avance 250 spectrometer $\left({ }^{1} \mathrm{H}\right.$ NMR: $250.12 \mathrm{MHz}$, ${ }^{13} \mathrm{C}\left\{{ }^{1} \mathrm{H}\right\}$ NMR: $\left.62.86 \mathrm{MHz}\right)$ or with a Varian Inova 300 spectrometer $\left({ }^{1} \mathrm{H}\right.$ NMR: $300.10 \mathrm{MHz},{ }^{13} \mathrm{C}\left\{{ }^{1} \mathrm{H}\right\}$ NMR: $75.47 \mathrm{MHz}$ ) in the Fourier transform mode. Chemical shifts are reported in $\delta$ units (parts per million) downfield

Table 2

Selected bond distances $(\AA)$, angles $\left({ }^{\circ}\right)$, and torsion angels $\left(^{\circ}\right)$ for $\mathbf{8}$ and $13^{\mathrm{a}}$

\begin{tabular}{|c|c|c|c|c|c|}
\hline \multicolumn{2}{|l|}{ Bond distances } & \multicolumn{2}{|l|}{ Bond angles } & \multicolumn{2}{|l|}{ Torsion angles } \\
\hline Complex $\boldsymbol{8}^{\mathrm{c}}$ & & & & & \\
\hline Pt1-Cl1 & $2.4452(9)$ & $\mathrm{Cl1}-\mathrm{Pt1}-\mathrm{C} 1$ & $177.57(11)$ & $\mathrm{C} 1-\mathrm{C} 2-\mathrm{C} 7-\mathrm{N} 1$ & $20.9(5)$ \\
\hline Pt1-C1 & $1.925(4)$ & N1-Pt1-N2 & $164.65(12)$ & $\mathrm{C} 1-\mathrm{C} 6-\mathrm{C} 10-\mathrm{N} 2$ & $22.4(5)$ \\
\hline Pt1-N1 & $2.092(3)$ & Cl1-Pt1-N1 & $96.19(9)$ & Pt1-N1-C7-C2 & $-25.6(4)$ \\
\hline Pt1-N2 & $2.092(3)$ & Cl1-Pt1-N2 & $99.15(9)$ & $\mathrm{Pt} 1-\mathrm{N} 2-\mathrm{C} 10-\mathrm{C} 6$ & $-27.8(4)$ \\
\hline $\mathrm{D} 1-\mathrm{Fe}^{\mathrm{b}}$ & $1.641(2)$ & $\mathrm{D} 1-\mathrm{Fe} 1-\mathrm{D} 2^{\mathrm{b}}$ & $178.77(15)$ & & \\
\hline $\mathrm{D} 2-\mathrm{Fe} 1^{\mathrm{b}}$ & $1.639(3)$ & & & & \\
\hline \multicolumn{6}{|l|}{ Complex 13} \\
\hline Pt1-Cl1 & $2.4304(15)$ & $\mathrm{Cl1}-\mathrm{Pt} 1-\mathrm{C} 1$ & 178.91(19) & $\mathrm{C} 1-\mathrm{C} 2-\mathrm{C} 7-\mathrm{N} 1$ & $25.0(7)$ \\
\hline $\mathrm{Pt} 1-\mathrm{C} 1$ & $1.914(6)$ & $\mathrm{N} 1-\mathrm{Pt} 1-\mathrm{N} 2$ & $163.09(19)$ & $\mathrm{C} 1-\mathrm{C} 6-\mathrm{C} 10-\mathrm{N} 2$ & $23.8(7)$ \\
\hline Pt1-N1 & $2.102(5)$ & Cl1-Pt1-N1 & $99.43(14)$ & Pt1-N1-C7-C2 & $-32.4(5)$ \\
\hline Pt1-N2 & $2.091(5)$ & Cl1-Pt1-N2 & $97.46(14)$ & Pt1-N2-C10-C6 & $-32.6(6)$ \\
\hline C13-C14 & $1.169(9)$ & $\mathrm{C} 4-\mathrm{C} 13-\mathrm{C} 14$ & $177.0(7)$ & & \\
\hline $\mathrm{Fe} 1-\mathrm{D} 1^{\mathrm{b}}$ & $1.634(3)$ & $\mathrm{C} 13-\mathrm{C} 14-\mathrm{C} 15$ & $177.3(7)$ & & \\
\hline $\mathrm{Fe} 1-\mathrm{D} 2^{\mathrm{b}}$ & $1.634(3)$ & $\mathrm{D} 1-\mathrm{Fe} 1-\mathrm{D} 2^{\mathrm{b}}$ & $177.75(17)$ & & \\
\hline
\end{tabular}

\footnotetext{
${ }^{a}$ Standard uncertainties are given in the last significant figure(s) in parenthesis.

${ }^{\mathrm{b}}$ D1, D2: centroids of the cyclopentadienyl ligands.

${ }^{c}$ Only one of the two independent molecules is considered.
} 
from tetramethylsilane $(\delta=0.00 \mathrm{ppm})$ with the solvent as the reference signal $\left(\mathrm{CDCl}_{3}:{ }^{1} \mathrm{H} \mathrm{NMR}, \delta=7.26 ;{ }^{13} \mathrm{C}\left\{{ }^{1} \mathrm{H}\right\}\right.$ NMR, $\delta=77.0$ ). Cyclicvoltammograms were recorded in a dried cell purged with purified nitrogen at $25^{\circ} \mathrm{C}$. Platinum wires served as working and as counter electrode. A $\mathrm{Ag} / \mathrm{AgCl}$ or a saturated calomel electrode served as reference electrode. For ease of comparison, all electrode potentials are converted using the redox potential of the ferrocene-ferrocenium couple $\mathrm{Cp}_{2} \mathrm{Fe} / \mathrm{Cp}_{2} \mathrm{Fe}^{+}\left(\mathrm{Cp}_{2} \mathrm{Fe}=\right.$ $\left.\left(\eta^{5}-\mathrm{C}_{5} \mathrm{H}_{5}\right)_{2} \mathrm{Fe}\right)$ as the reference $\left(E_{1 / 2}=0.00 \mathrm{~V}\right)$ [17]. Electrolyte solutions were prepared from freshly distilled acetonitrile or tetrahydrofuran and $\left[n-\mathrm{Bu}_{4} \mathrm{~N}\right] \mathrm{PF}_{6}$ (dried in oil-pump vacuum at $120^{\circ} \mathrm{C}, c=0.1 \mathrm{M}$ ). The appropriate organometallic compounds were added at $c=1.0 \mathrm{mM}$. The cyclicvoltammograms were recorded at a scan rate of $200 \mathrm{mV} \mathrm{s}^{-1}$ using a Princeton Applied Research EG\&G 263A Analyser or a Radiometer Copenhagen DEA 101 Digital Electrochemical Analyser with an IMT 102 electrochemical interface. Melting points were determined using sealed nitrogen purged capillaries on a Gallenkamp MFB $595010 \mathrm{M}$ melting point apparatus. Microanalyses were performed by the Dornis und Kolbe, Mikroanalytisches Laboratorium, Mülheim a. d. Ruhr and by the Department of Organic Chemistry at Chemnitz, Technical University.

\subsection{General remarks}

$\mathrm{Fc}-\mathrm{B}(\mathrm{OH})_{2}$ (1) [18], I-1- $\mathrm{C}_{6} \mathrm{H}_{3}\left(\mathrm{CH}_{2} \mathrm{NMe}_{2}\right)_{2}-3,5$ (2) [19], $\mathrm{Fc}-\mathrm{C} \equiv \mathrm{CH}$ (4) [20], $\left[\mathrm{PdCl}_{2}\left(\mathrm{SEt}_{2}\right)_{2}\right] \quad[21], \quad\left[\mathrm{PtCl}_{2}\left(\mathrm{SEt}_{2}\right)_{2}\right]$ $[21,22], \quad\left[\mathrm{Pd}_{2}(\mathrm{dba})_{3} \cdot \mathrm{CHCl}_{3}\right][23]$, and $\left[\mathrm{Pt}(4-\mathrm{tol})_{2}\left(\mathrm{SEt}_{2}\right)\right]_{2}$ [24] were prepared the following published procedures. All other chemicals were commercially available and were used as received.

\subsection{Synthesis of $\mathbf{3}$}

Compound $1(1.60 \mathrm{~g}, 6.96 \mathrm{mmol})$ and $2.22 \mathrm{~g}(6.96 \mathrm{mmol})$ of 2 were dissolved in $50 \mathrm{~mL}$ of dimethoxymethane and $15 \mathrm{~mL}$ of $3 \mathrm{M} \mathrm{NaOH}$ were added. Afterward $50 \mathrm{mg}$ $(0.07 \mathrm{mmol}, 1.0 \mathrm{~mol} \%)$ of $\left[(\mathrm{dppf}) \mathrm{PdCl}_{2}\right]$ were added at $25^{\circ} \mathrm{C}$. After keeping the reaction mixture for 6 days at reflux it was cooled to $25^{\circ} \mathrm{C}$, dissolved in $100 \mathrm{~mL}$ of chloroform followed by addition of $100 \mathrm{~mL}$ of water. The aqueous phase was extracted three times with $100 \mathrm{~mL}$ of diethyl ether. The combined organic phases were dried over $\mathrm{MgSO}_{4}$, filtered and then all volatiles were evaporated from the filtrate (oil-pump vacuum). Chromatography on neutral alumina $(5 \times 15 \mathrm{~cm})$ with diethyl ether gave $120 \mathrm{mg}$ $(0.65 \mathrm{mmol}, 9 \%$ based on $\mathbf{1})$ of recovered $\mathrm{Fc}-\mathrm{B}(\mathrm{OH})_{2}$. By changing the solvent to diethyl ether-tetrahydrofuran (ratio 1:2) 3 has been obtained as a red oil. Yield: $710 \mathrm{mg}$ (1.89 mmol, $27 \%$ based on $\mathbf{1}$ ).

${ }^{1} \mathrm{H}$ NMR $\left(\mathrm{CDCl}_{3}\right):[\delta] 2.26\left(\mathrm{~s}, 12 \mathrm{H}, \mathrm{NM} e_{2}\right), 3.43(\mathrm{~s}, 4 \mathrm{H}$, $\left.\mathrm{CH}_{2} \mathrm{~N}\right), 4.02\left(\mathrm{~s}, 5 \mathrm{H}, \mathrm{C}_{5} H_{5}\right), 4.29\left(\mathrm{pt}, J_{\mathrm{HH}}=1.8 \mathrm{~Hz}, 2 \mathrm{H}\right.$, $\left.\mathrm{C}_{5} H_{4}\right), 4.67\left(\mathrm{pt}, J_{\mathrm{HH}}=1.8 \mathrm{~Hz}, 2 \mathrm{H}, \mathrm{C}_{5} H_{4}\right), 7.07(\mathrm{~s}, 1 \mathrm{H}$, $\left.\mathrm{C}_{6} H_{3}\right), 7.31\left(\mathrm{~s}, 2 \mathrm{H}, \mathrm{C}_{6} H_{3}\right) \cdot{ }^{13} \mathrm{C}\left\{{ }^{1} \mathrm{H}\right\}$ NMR $\left(\mathrm{CDCl}_{3}\right)$ : $[\delta]$ $45.4\left(\mathrm{NCH}_{3}\right), 64.4\left(\mathrm{NCH}_{2}\right), 66.6\left(\mathrm{CH} / \mathrm{C}_{5} \mathrm{H}_{4}\right), 68.8(\mathrm{CH} /$
$\left.\mathrm{C}_{5} \mathrm{H}_{4}\right), 69.5\left(\mathrm{CH} / \mathrm{C}_{5} \mathrm{H}_{5}\right), 85.3\left({ }^{i} \mathrm{C} / \mathrm{C}_{5} \mathrm{H}_{4}\right), 125.6(\mathrm{CH} /$ $\left.\mathrm{C}_{6} \mathrm{H}_{3}\right), 127.7\left(\mathrm{CH} / \mathrm{C}_{6} \mathrm{H}_{3}\right), 138.7\left({ }^{i} \mathrm{C} / \mathrm{C}_{6} \mathrm{H}_{3}\right), 139.0\left({ }^{i} \mathrm{Cl}\right.$ $\mathrm{C}_{6} \mathrm{H}_{3}$ ). Anal. Calc. for $\mathrm{C}_{22} \mathrm{H}_{28} \mathrm{FeN}_{2}(376.31)$ : C, 70.18; H, 7.50; N, 7.45. Found: C, 69.69; H, 7.57; N, 7.53\%.

\subsection{Synthesis of 5}

Compound 4 (294 mg, $1.4 \mathrm{mmol}), 318 \mathrm{mg}(1.0 \mathrm{mmol})$ of 2, $35 \mathrm{mg}(0.05 \mathrm{mmol}, 5.0 \mathrm{~mol} \%)$ of $\left[\left(\mathrm{Ph}_{3} \mathrm{P}\right)_{2} \mathrm{PdCl}_{2}\right]$ and 10 $\mathrm{mg}(0.05 \mathrm{mmol}, 5.0 \mathrm{~mol} \%)$ of $[\mathrm{CuI}]$ were dissolved in $20 \mathrm{~mL}$ of ${ }^{i} \operatorname{Pr}_{2} \mathrm{NH}$. The reaction mixture was heated for 5 $\mathrm{h}$ to reflux and was then evaporated in oil-pump vacuum. Chromatography on neutral alumina $(5 \times 15 \mathrm{~cm})$ with diethyl ether yielded $20 \mathrm{mg}(0.10 \mathrm{mmol}, 7 \%$ based on 2$)$ of recovered 4 . By changing the solvent to tetrahydrofuran compound $\mathbf{5}$ could be isolated as orange-red oil. Yield: $300 \mathrm{mg}$ ( $0.75 \mathrm{mmol}, 75 \%$ based on 2$)$.

IR (NaCl): $\left[\mathrm{cm}^{-1}\right] 2212$ (s) $\left[v_{\mathrm{C}}=\mathrm{C}\right] .{ }^{1} \mathrm{H}$ NMR $\left(\mathrm{CDCl}_{3}\right)$ :

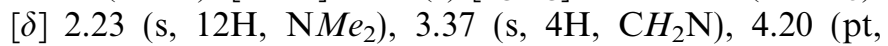
$\left.J_{\mathrm{HH}}=1.5 \mathrm{~Hz}, 2 \mathrm{H}, \mathrm{C}_{5} H_{4}\right), 4.21\left(\mathrm{~s}, 5 \mathrm{H}, \mathrm{C}_{5} H_{5}\right), 4.45(\mathrm{pt}$, $\left.J_{\mathrm{HH}}=1.5 \mathrm{~Hz}, 2 \mathrm{H}, \mathrm{C}_{5} H_{4}\right), 7.18\left(\mathrm{~s}, 1 \mathrm{H}, \mathrm{C}_{6} H_{3}\right), 7.33(\mathrm{~s}, 2 \mathrm{H}$, $\left.\mathrm{C}_{6} \mathrm{H}_{3}\right) \cdot{ }^{13} \mathrm{C}\left\{{ }^{1} \mathrm{H}\right\}$ NMR $\left(\mathrm{CDCl}_{3}\right):[\delta] 45.3\left(\mathrm{NCH}_{3}\right), 63.9$ $\left(\mathrm{NCH}_{2}\right), 65.3\left({ }^{i} \mathrm{C} / \mathrm{C}_{5} \mathrm{H}_{4}\right), 68.7\left(\mathrm{CH} / \mathrm{C}_{5} \mathrm{H}_{4}\right), 69.9(\mathrm{CH} /$ $\left.\mathrm{C}_{5} \mathrm{H}_{5}\right), 71.3\left(\mathrm{CH} / \mathrm{C}_{5} \mathrm{H}_{4}\right), 85.7(\mathrm{FcC} \equiv \mathrm{C}), 88.1(\mathrm{FcC} \equiv \mathrm{C})$, $123.8\left({ }^{i} \mathrm{C} / \mathrm{C}_{6} \mathrm{H}_{3}\right), 129.1\left(\mathrm{CH} / \mathrm{C}_{6} \mathrm{H}_{3}\right), 130.7\left(\mathrm{CH} / \mathrm{C}_{6} \mathrm{H}_{3}\right)$, $138.9\left({ }^{i} C^{C} / \mathrm{C}_{6} \mathrm{H}_{3}\right)$. Anal. Calc. for $\mathrm{C}_{24} \mathrm{H}_{28} \mathrm{FeN}_{2}$ (400.33): $\mathrm{C}$, $72.00 ; \mathrm{H}, 7.05 ; \mathrm{N}, 7.00$. Found: C, 71.84; H, 6.92; N, 6.90\%.

\subsection{Synthesis of 6}

Complex 3 (160 mg, $0.43 \mathrm{mmol}$ ) was dissolved in $30 \mathrm{~mL}$ of $n$-hexane and $0.35 \mathrm{~mL}(0.56 \mathrm{mmol}, 1.6 \mathrm{M}$ solution in $n$ hexane) of ${ }^{n} \mathrm{BuLi}$ were added at $25^{\circ} \mathrm{C}$. After stirring the reaction mixture for $16 \mathrm{~h}$ at this temperature all volatiles were removed (oil-pump vacuum). The orange residue was dissolved in $30 \mathrm{~mL}$ of diethyl ether, treated with $200 \mathrm{mg}$ $(0.79 \mathrm{mmol})$ of $\mathrm{I}_{2}$ and stirred for $6 \mathrm{~h}$ at $25^{\circ} \mathrm{C}$. A solution of $1.0 \mathrm{~g} \mathrm{Na}_{2} \mathrm{~S}_{2} \mathrm{O}_{3}$ in $50 \mathrm{~mL}$ of water was then added. The organic phase was separated, extracted with $50 \mathrm{~mL}$ of water, dried over $\mathrm{MgSO}_{4}$, filtered and evaporated in oilpump vacuum to gave $175 \mathrm{mg}(0.35 \mathrm{mmol}, 82 \%$ based on 3) of 6 as an orange oil.

${ }^{1} \mathrm{H} \mathrm{NMR}\left(\mathrm{CDCl}_{3}\right):[\delta] 2.35$ (s, 12H, NMe $), 3.54(\mathrm{~s}, 4 \mathrm{H}$, $\left.\mathrm{CH}_{2} \mathrm{~N}\right), 4.03\left(\mathrm{~s}, 5 \mathrm{H}, \mathrm{C}_{5} H_{5}\right), 4.32\left(\mathrm{pt}, J_{\mathrm{HH}}=1.8 \mathrm{~Hz}, 2 \mathrm{H}\right.$, $\left.\mathrm{C}_{5} H_{4}\right), 4.71\left(\mathrm{pt}, J_{\mathrm{HH}}=1.8 \mathrm{~Hz}, 2 \mathrm{H}, \mathrm{C}_{5} H_{4}\right), 7.40(\mathrm{~s}, 2 \mathrm{H}$, $\left.\mathrm{C}_{6} \mathrm{H}_{2}\right) .{ }^{13} \mathrm{C}\left\{{ }^{1} \mathrm{H}\right\} \quad \mathrm{NMR}\left(\mathrm{CDCl}_{3}\right):[\delta] 45.5\left(\mathrm{NCH}_{3}\right), 66.6$ $\left(\mathrm{CH} / \mathrm{C}_{5} \mathrm{H}_{4}\right), 69.0\left(\mathrm{NCH}_{2}\right), 69.0\left(\mathrm{CH} / \mathrm{C}_{5} \mathrm{H}_{4}\right), 69.5(\mathrm{CH} /$ $\left.\mathrm{C}_{5} \mathrm{H}_{5}\right), 84.1 \quad\left({ }^{i} \mathrm{C} / \mathrm{C}_{5} \mathrm{H}_{4}\right), 103.9\left({ }^{i} \mathrm{CI} / \mathrm{C}_{6} \mathrm{H}_{2}\right), 126.6(\mathrm{CH} /$ $\left.\mathrm{C}_{6} \mathrm{H}_{2}\right), 138.7\left({ }^{i} \mathrm{C} / \mathrm{C}_{6} \mathrm{H}_{2}\right), 141.5\left({ }^{i} C / \mathrm{C}_{6} \mathrm{H}_{2}\right)$. Anal. Calc. for $\mathrm{C}_{22} \mathrm{H}_{27} \mathrm{FeIN}_{2}$ (502.21): C, 52.61; H, 5.42; N, 5.58. Found: C, $52.01 ; \mathrm{H}, 5.29 ; \mathrm{N}, 5.76 \%$.

\subsection{Synthesis of 7}

Complex 3 (100 mg, $0.28 \mathrm{mmol}$ ) was dissolved in $30 \mathrm{~mL}$ of $n$-hexane and $0.18 \mathrm{~mL}(0.28 \mathrm{mmol}, 1.6 \mathrm{M}$ solution in $n$-hexane) of ${ }^{n} \mathrm{BuLi}$ were drop-wise added at $25^{\circ} \mathrm{C}$. After- 
wards, the reaction mixture was stirred for $18 \mathrm{~h}$ at this temperature and then all volatiles were removed (oil-pump vacuum). The orange residue was dissolved in $30 \mathrm{~mL}$ of diethyl ether, treated with $100 \mathrm{mg}(0.28 \mathrm{mmol})$ of $\left[\left(\mathrm{Et}_{2} \mathrm{~S}\right)_{2} \mathrm{PdCl}_{2}\right]$ and stirred for $18 \mathrm{~h}$ at room temperature. During this time a precipitate formed which was collected and dried in oilpump vacuum. The orange solid was dissolved in $30 \mathrm{~mL}$ of dichloromethane, filtered through a pad of Celite and dried (oil-pump vacuum) to gave $110 \mathrm{mg}(0.21 \mathrm{mmol}, 76 \%$ based on $\left.\left[\left(\mathrm{Et}_{2} \mathrm{~S}\right)_{2} \mathrm{PdCl}_{2}\right)\right]$ of $\mathbf{7}$ as an orange solid.

M.p.: $\left[{ }^{\circ} \mathrm{C}\right] 93$ (dec.). ${ }^{1} \mathrm{H}$ NMR $\left(\mathrm{CDCl}_{3}\right):[\delta] 2.97(\mathrm{~s}, 12 \mathrm{H}$, $\left.\mathrm{N} M e_{2}\right), 4.02\left(\mathrm{~s}, 4 \mathrm{H}, \mathrm{CH}_{2} \mathrm{~N}\right), 4.04\left(\mathrm{~s}, 5 \mathrm{H}, \mathrm{C}_{5} \mathrm{H}_{5}\right), 4.26(\mathrm{pt}$, $\left.J_{\mathrm{HH}}=1.8 \mathrm{~Hz}, 2 \mathrm{H}, \mathrm{C}_{5} H_{4}\right), 4.50\left(\mathrm{pt}, J_{\mathrm{HH}}=1.8 \mathrm{~Hz}, 2 \mathrm{H}\right.$, $\left.\mathrm{C}_{5} \mathrm{H}_{4}\right), 6.90\left(\mathrm{~s}, 2 \mathrm{H}, \mathrm{C}_{6} \mathrm{H}_{2}\right) .{ }^{13} \mathrm{C}\left\{{ }^{1} \mathrm{H}\right\}$ NMR $\left(\mathrm{CDCl}_{3}\right):[\delta]$ $53.1\left(\mathrm{NCH}_{3}\right), 66.2\left(\mathrm{CH} / \mathrm{C}_{5} \mathrm{H}_{4}\right), 68.6\left(\mathrm{CH} / \mathrm{C}_{5} \mathrm{H}_{4}\right), 69.5$ $\left(\mathrm{CH} / \mathrm{C}_{5} \mathrm{H}_{5}\right), 74.7\left(\mathrm{NCH}_{2}\right), 86.4\left({ }^{i} \mathrm{C} / \mathrm{C}_{5} \mathrm{H}_{4}\right), 117.7(\mathrm{CH} /$ $\left.\mathrm{C}_{6} \mathrm{H}_{2}\right), \quad 135.7 \quad\left({ }^{i} \mathrm{C} / \mathrm{C}_{6} \mathrm{H}_{2}\right), \quad 144.9 \quad\left({ }^{i} C_{6} / \mathrm{C}_{6} \mathrm{H}_{2}\right), 154.2\left({ }^{i} \mathrm{C} /\right.$ $\mathrm{C}_{6} \mathrm{H}_{2}$ ). Anal. Calc. for $\mathrm{C}_{22} \mathrm{H}_{27} \mathrm{ClFeN}_{2} \mathrm{Pd}$ (517.18): C, 51.09; H, 5.26; N, 5.42. Found: C, 51.19; H, 5.26; N, 5.82\%.

\subsection{Synthesis of $\boldsymbol{8}$}

Complex $3(110 \mathrm{mg}, 0.29 \mathrm{mmol})$ was dissolved in $20 \mathrm{~mL}$ of $n$-hexane and $0.19 \mathrm{~mL}(0.30 \mathrm{mmol}, 1.6 \mathrm{M}$ solution in $n$ hexane) of ${ }^{n} \mathrm{BuLi}$ were drop-wise added at $25^{\circ} \mathrm{C}$. The reaction mixture was stirred for $18 \mathrm{~h}$ at room temperature. Afterward, all volatiles were removed in oil-pump vacuum. The orange residue was dissolved in $20 \mathrm{~mL}$ of diethyl ether, treated with $130 \mathrm{mg}(0.29 \mathrm{mmol})$ of $\left[\left(\mathrm{Et}_{2} \mathrm{~S}\right)_{2} \mathrm{PtCl}_{2}\right]$ and stirred for $5 \mathrm{~h}$ at $25^{\circ} \mathrm{C}$. During this time a precipitate formed which was collected and dried (oil-pump vacuum). The orange solid was dissolved in dichloromethane, filtered through a pad of Celite and dried in oil-pump vacuum to gave $130 \mathrm{mg}\left(0.21 \mathrm{mmol}, 74 \%\right.$ based on $\left.\left[\left(\mathrm{Et}_{2} \mathrm{~S}\right)_{2} \mathrm{PtCl}_{2}\right]\right)$ of 8 as an orange solid.

M.p.: $\left[{ }^{\circ} \mathrm{C}\right] 95$ (dec.). ${ }^{1} \mathrm{H}$ NMR $\left(\mathrm{CDCl}_{3}\right):[\delta] 3.11$ (s, $\left.{ }^{3} J_{\mathrm{PtH}}=38.4 \mathrm{~Hz}, 12 \mathrm{H}, \mathrm{NMe} 2\right), 4.05\left(\mathrm{~s},{ }^{3} J_{\mathrm{PtH}}=46.6 \mathrm{~Hz}\right.$, $\left.4 \mathrm{H}, \mathrm{CH}_{2} \mathrm{~N}\right), 4.05\left(\mathrm{~s}, 5 \mathrm{H}, \mathrm{C}_{5} H_{5}\right), 4.25\left(\mathrm{pt}, J_{\mathrm{HH}}=1.8 \mathrm{~Hz}\right.$, $\left.2 \mathrm{H}, \mathrm{C}_{5} H_{4}\right), 4.51\left(\mathrm{pt}, J_{\mathrm{HH}}=1.8 \mathrm{~Hz}, 2 \mathrm{H}, \mathrm{C}_{5} H_{4}\right), 6.94(\mathrm{~s}$, $\left.2 \mathrm{H}, \mathrm{C}_{6} \mathrm{H}_{2}\right) \cdot{ }^{13} \mathrm{C}\left\{{ }^{1} \mathrm{H}\right\}$ NMR $\left(\mathrm{CDCl}_{3}\right):[\delta] 54.4\left(\mathrm{NCH}_{3}\right)$, $66.0\left(\mathrm{CH} / \mathrm{C}_{5} \mathrm{H}_{4}\right), 68.3\left(\mathrm{CH} / \mathrm{C}_{5} \mathrm{H}_{4}\right), 69.4\left(\mathrm{CH} / \mathrm{C}_{5} \mathrm{H}_{5}\right), 77.7$ $\left(\mathrm{NCH}_{2}\right), 87.5\left({ }^{i} \mathrm{C} / \mathrm{C}_{5} \mathrm{H}_{4}\right), 117.4\left(\mathrm{CH} / \mathrm{C}_{6} \mathrm{H}_{2}\right), 134.1\left({ }^{i} \mathrm{Cl}\right.$ $\left.\mathrm{C}_{6} \mathrm{H}_{2}\right), 143.1\left({ }^{i} \mathrm{CPt} / \mathrm{C}_{6} \mathrm{H}_{2}\right), 143.2\left({ }^{i} \mathrm{C} / \mathrm{C}_{6} \mathrm{H}_{3}\right)$. Anal. Calc. for $\mathrm{C}_{22} \mathrm{H}_{27} \mathrm{ClFeN}_{2} \mathrm{Pt}(605.84)$ ): C, 43.61; H, 4.46; N, 4.62. Found: C, 43.81; H, 4.58; N, 4.53\%.

\subsection{Synthesis of 9}

Compound $\quad 6 \quad(100 \mathrm{mg}, \quad 0.20 \mathrm{mmol})$ and $90 \mathrm{mg}$ $(0.10 \mathrm{mmol})$ of $\left[\mathrm{Pt}(\mathrm{tol})_{2}\left(\mathrm{SEt}_{2}\right)\right]_{2}$ were dissolved in $20 \mathrm{~mL}$ of toluene and were heated to reflux for $5 \mathrm{~min}$. The obtained orange solution was then cooled to $25^{\circ} \mathrm{C}$ and concentrated in oil-pump vacuum to $5 \mathrm{~mL}$. Upon addition of $20 \mathrm{~mL}$ of $n$-hexane an orange precipitate formed which was collected, washed twice with $10 \mathrm{~mL}$ of hexane and $10 \mathrm{~mL}$ of diethyl ether and dried in oil-pump vacuum. Yield: $95 \mathrm{mg}\left(0.14 \mathrm{mmol}, 71 \%\right.$ based on $\left.\left[\mathrm{Pt}(\mathrm{tol})_{2}\left(\mathrm{SEt}_{2}\right)\right]_{2}\right)$.
M.p.: $\left[{ }^{\circ} \mathrm{C}\right] 92$ (dec). ${ }^{1} \mathrm{H}$ NMR $\left(\mathrm{CDCl}_{3}\right):[\delta] 3.20$ (s, $\left.{ }^{3} J_{\mathrm{PtH}}=38.9 \mathrm{~Hz}, 12 \mathrm{H}, \mathrm{N} M e_{2}\right), 4.03\left(\mathrm{~s},{ }^{3} J_{\mathrm{PtH}}=46.4 \mathrm{~Hz}\right.$, $\left.4 \mathrm{H}, \mathrm{CH}_{2} \mathrm{~N}\right), 4.03\left(\mathrm{~s}, 5 \mathrm{H}, \mathrm{C}_{5} H_{5}\right), 4.25\left(\mathrm{pt}, J_{\mathrm{HH}}=1.7 \mathrm{~Hz}\right.$, $\left.2 \mathrm{H}, \mathrm{C}_{5} H_{4}\right), 4.52\left(\mathrm{pt}, J_{\mathrm{HH}}=1.7 \mathrm{~Hz}, 2 \mathrm{H}, \mathrm{C}_{5} H_{4}\right), 6.93(\mathrm{~s}$, $\left.2 \mathrm{H}, \mathrm{C}_{6} \mathrm{H}_{2}\right) .{ }^{13} \mathrm{C}\left\{{ }^{1} \mathrm{H}\right\}$ NMR $\left(\mathrm{CDCl}_{3}\right)$ : $[\delta] 56.3\left(\mathrm{NCH}_{3}\right)$, $66.0\left(\mathrm{CH} / \mathrm{C}_{5} \mathrm{H}_{4}\right), 68.4\left(\mathrm{CH} / \mathrm{C}_{5} \mathrm{H}_{4}\right), 69.4\left(\mathrm{CH} / \mathrm{C}_{5} \mathrm{H}_{5}\right), 76.8$ $\left(\mathrm{NCH}_{2}\right), 87.1\left({ }^{i} \mathrm{C} / \mathrm{C}_{5} \mathrm{H}_{4}\right), 117.3\left(\mathrm{CH} / \mathrm{C}_{6} \mathrm{H}_{2}\right), 134.4\left({ }^{i} \mathrm{C} /\right.$ $\left.\mathrm{C}_{6} \mathrm{H}_{2}\right), 143.4\left({ }^{i} \mathrm{C} / \mathrm{C}_{6} \mathrm{H}_{3}\right), 147.5\left({ }^{i} C P t / \mathrm{C}_{6} \mathrm{H}_{2}\right)$. Anal. Calc. for $\mathrm{C}_{22} \mathrm{H}_{27} \mathrm{FeIN}{ }_{2} \mathrm{Pt}$ (697.29): C, 37.89; H, 3.90; N, 4.02. Found: C, 36.81; H, 4.58; N, 4.53\%.

\subsection{Synthesis of $\mathbf{1 0}$}

Complex 10 was prepared according to the procedure described for 6 by using $62 \mathrm{mg}(0.15 \mathrm{mmol})$ of $5,0.15 \mathrm{~mL}$ $\left(0.24 \mathrm{mmol}, 1.6 \mathrm{M}\right.$ in $n$-hexane) of ${ }^{n} \mathrm{BuLi}$ and $70 \mathrm{mg}$ $(0.28 \mathrm{mmol})$ of $\mathrm{I}_{2}$. Yield: $65 \mathrm{mg}(0.12 \mathrm{mmol}, 80 \%$ based on 5 ).

IR ( $\mathrm{NaCl}):\left[\mathrm{cm}^{-1}\right] 2211$ (s) $\left[v_{\mathrm{C}} \mathrm{C}_{\mathrm{C}}\right]{ }^{1} \mathrm{H}$ NMR $\left(\mathrm{CDCl}_{3}\right)$ :

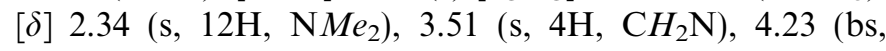
$\left.7 \mathrm{H}, \mathrm{C}_{5} H_{4}, \mathrm{C}_{5} H_{5}\right), 4.48\left(\mathrm{pt}, J_{\mathrm{HH}}=1.8 \mathrm{~Hz}, 2 \mathrm{H}, \mathrm{C}_{5} H_{4}\right)$, $7.40\left(\mathrm{~s}, 2 \mathrm{H}, \mathrm{C}_{6} \mathrm{H}_{2}\right) .{ }^{13} \mathrm{C}\left\{{ }^{1} \mathrm{H}\right\}$ NMR $\left(\mathrm{CDCl}_{3}\right):[\delta] 45.6$ $\left(\mathrm{NCH}_{3}\right), 65.1\left({ }^{i} \mathrm{C} / \mathrm{C}_{5} \mathrm{H}_{4}\right), 68.8\left(\mathrm{NCH}_{2}\right), 68.8\left(\mathrm{CH} / \mathrm{C}_{5} \mathrm{H}_{4}\right)$, $69.9\left(\mathrm{CH} / \mathrm{C}_{5} \mathrm{H}_{5}\right), 71.3\left(\mathrm{CH} / \mathrm{C}_{5} \mathrm{H}_{4}\right), 85.1(\mathrm{FcC} \equiv \mathrm{C}), 89.4$ $(\mathrm{FcC} \equiv \mathrm{C}), 106.3\left({ }^{i} \mathrm{CI} / \mathrm{C}_{6} \mathrm{H}_{2}\right), 123.5\left({ }^{i} \mathrm{C} / \mathrm{C}_{6} \mathrm{H}_{2}\right), 131.3(\mathrm{CH} /$ $\left.\mathrm{C}_{6} \mathrm{H}_{2}\right), 141.9\left({ }^{i} \mathrm{C} / \mathrm{C}_{6} \mathrm{H}_{2}\right)$. Anal. Calc. for $\mathrm{C}_{24} \mathrm{H}_{27} \mathrm{FeIN}_{2}$ (526.23): C, 54.78; H, 5.17; N, 5.32. Found: C, 57.30; H, $6.57 ; \mathrm{N}, 3.34 \%$.

\subsection{Synthesis of $\mathbf{1 1}$}

Heterobimetallic $\mathbf{1 1}$ was prepared according to the procedure described for 7 . In this respect, $100 \mathrm{mg}(0.25 \mathrm{mmol})$ of 5, $0.15 \mathrm{~mL}$ ( $0.38 \mathrm{mmol}, 2.5 \mathrm{M}$ in $n$-hexane) of ${ }^{n} \mathrm{BuLi}$ and $90 \mathrm{mg}(0.25 \mathrm{mmol})$ of $\left[\left(\mathrm{Et}_{2} \mathrm{~S}\right)_{2} \mathrm{PdCl}_{2}\right]$ were reacted. Yield: $40 \mathrm{mg}(0.07 \mathrm{mmol}, 29 \%$ based on $\mathbf{5})$.

M.p.: $\left[{ }^{\circ} \mathrm{C}\right] 102$ (dec.). (KBr): $\left[\mathrm{cm}^{-1}\right] 2211(\mathrm{w})\left[v_{\mathrm{C}} \equiv \mathrm{C}\right] \cdot{ }^{1} \mathrm{H}$ NMR $\left(\mathrm{CDCl}_{3}\right):[\delta] 2.92(\mathrm{~s}, 12 \mathrm{H}, \mathrm{NMe}), 3.96(\mathrm{~s}, 4 \mathrm{H}$, $\left.\mathrm{CH}_{2} \mathrm{~N}\right), 4.20\left(\mathrm{~s}, 5 \mathrm{H}, \mathrm{C}_{5} H_{5}\right), 4.22\left(\mathrm{pt}, J_{\mathrm{HH}}=1.8 \mathrm{~Hz}, 2 \mathrm{H}\right.$, $\left.\mathrm{C}_{5} H_{4}\right), 4.44\left(\mathrm{pt}, J_{\mathrm{HH}}=1.8 \mathrm{~Hz}, 2 \mathrm{H}, \mathrm{C}_{5} H_{4}\right), 6.90(\mathrm{~s}, 2 \mathrm{H}$, $\left.\mathrm{C}_{6} \mathrm{H}_{2}\right) \cdot{ }^{13} \mathrm{C}\left\{{ }^{1} \mathrm{H}\right\}$ NMR $\left(\mathrm{CDCl}_{3}\right):[\delta] 53.0\left(\mathrm{NCH}_{3}\right), 66.2$ $\left(\mathrm{CH} / \mathrm{C}_{5} \mathrm{H}_{4}\right), \quad 68.7 \quad\left(\mathrm{CH} / \mathrm{C}_{5} \mathrm{H}_{4}\right), \quad 69.8 \quad\left(\mathrm{CH} / \mathrm{C}_{5} \mathrm{H}_{5}\right), \quad 74.7$ $\left(\mathrm{NCH}_{2}\right), 86.4\left({ }^{i} \mathrm{C} / \mathrm{C}_{5} \mathrm{H}_{4}\right), 122.6\left(\mathrm{CH} / \mathrm{C}_{6} \mathrm{H}_{2}\right), 135.7\left({ }^{i} \mathrm{C} /\right.$ $\left.\mathrm{C}_{6} \mathrm{H}_{2}\right), 144.9\left({ }^{i} \mathrm{C} / \mathrm{C}_{6} \mathrm{H}_{2}\right), 154.2\left({ }^{i} \mathrm{C} / \mathrm{C}_{6} \mathrm{H}_{2}\right)$. Anal. Calc. for $\mathrm{C}_{24} \mathrm{H}_{27} \mathrm{ClFeN}_{2} \mathrm{Pd}$ (541.20): C, 53.26; H, 5.03; N, 5.18. Found: C, 53.38; H, 5.28; N, 5.67\%.

\subsection{Synthesis of $\mathbf{1 2}$}

Complex $10 \quad(50 \mathrm{mg}, \quad 0.095 \mathrm{mmol})$ and $45 \mathrm{mg}$ $(0.043 \mathrm{mmol})$ of $\left[\mathrm{Pd}_{2}(\mathrm{dba})_{3} \cdot \mathrm{CHCl}_{3}\right]$ were dissolved in $15 \mathrm{~mL}$ of benzene. This reaction mixture was stirred for $18 \mathrm{~h}$ at $25^{\circ} \mathrm{C}$. Afterwards, $20 \mathrm{~mL}$ of tetrahydrofuran were added and stirring was continued for $2 \mathrm{~h}$. All volatiles were evaporated in oil-pump vacuum and the residual greenishblack solid was dissolved in $20 \mathrm{~mL}$ of chloroform. The solution was filtered through a pad of Celite and concen- 
trated in oil-pump vacuum to $2 \mathrm{~mL}$. $n$-Hexane $(50 \mathrm{~mL})$ was added, whereby an orange solid precipitated. This precipitate was collected and washed several times with $10 \mathrm{~mL}$ of $n$-hexane and $10 \mathrm{~mL}$ of diethyl ether to gave $\mathbf{1 2}$ as an orange solid. Yield: $40 \mathrm{mg}(0.063 \mathrm{mmol}, 73 \%$ based on $\left.\left[\mathrm{Pd}_{2}(\mathrm{dba})_{3} \cdot \mathrm{CHCl}_{3}\right]\right)$.

M.p.: $\left[{ }^{\circ} \mathrm{C}\right] 106$ (dec.). IR (KBr): $\left[\mathrm{cm}^{-1}\right] 2210(\mathrm{w})\left[v_{\mathrm{C} \equiv \mathrm{C}}\right]$. ${ }^{1} \mathrm{H}$ NMR $\left(\mathrm{CDCl}_{3}\right):[\delta] 3.02$ (s, 12H, NMe $\left.e_{2}\right), 3.96(\mathrm{~s}, 4 \mathrm{H}$, $\left.\mathrm{CH}_{2} \mathrm{~N}\right), 4.22\left(\mathrm{bs}, 2 \mathrm{H}, \mathrm{C}_{5} \mathrm{H}_{4}\right), 4.22\left(\mathrm{bs}, 5 \mathrm{H}, \mathrm{C}_{5} \mathrm{H}_{5}\right), 4.46$ $\left(\mathrm{pt}, \quad J_{\mathrm{HH}}=1.8 \mathrm{~Hz}, 2 \mathrm{H}, \mathrm{C}_{5} H_{4}\right), 6.92\left(\mathrm{~s}, 2 \mathrm{H}, \quad \mathrm{C}_{6} H_{2}\right)$. ${ }^{13} \mathrm{C}\left\{{ }^{1} \mathrm{H}\right\} \quad$ NMR $\left(\mathrm{CDCl}_{3}\right):[\delta] 54.9\left(\mathrm{NCH}_{3}\right), 65.4\left({ }^{i} \mathrm{C} /\right.$ $\left.\mathrm{C}_{5} \mathrm{H}_{4}\right), 68.8\left(\mathrm{CH} / \mathrm{C}_{5} \mathrm{H}_{4}\right), 69.9\left(\mathrm{CH} / \mathrm{C}_{5} \mathrm{H}_{5}\right), 71.3(\mathrm{CH} /$ $\left.\mathrm{C}_{5} \mathrm{H}_{4}\right), 77.3\left(\mathrm{NCH}_{2}\right), 73.8(\mathrm{Fc} C \equiv \mathrm{C}), 86.0(\mathrm{FcC} \equiv C)$, $120.0 \quad\left({ }^{i} \mathrm{C} / \mathrm{C}_{6} \mathrm{H}_{2}\right), \quad 122.7 \quad\left(\mathrm{CH} / \mathrm{C}_{6} \mathrm{H}_{2}\right), \quad 128.3 \quad\left({ }^{i} \mathrm{C} / \mathrm{C}_{6} \mathrm{H}_{2}\right)$, $145.2\left({ }^{i} \mathrm{C} / \mathrm{C}_{6} \mathrm{H}_{2}\right)$. Anal. Calc. for $\mathrm{C}_{24} \mathrm{H}_{27} \mathrm{IFeN}_{2} \mathrm{Pd}(632.65)$ : $\mathrm{C}, 45.56 ; \mathrm{H}, 4.30 ; \mathrm{N}, 4.43$. Found: $\mathrm{C}, 45.71 ; \mathrm{H}, 4.38 ; \mathrm{N}$, $4.41 \%$.

\subsection{Synthesis of 13}

Compound 13 was prepared according to the procedure described for 8 by using $100 \mathrm{mg}(0.25 \mathrm{mmol})$ of $5,0.16 \mathrm{~mL}$ $\left(0.26 \mathrm{mmol}, 1.6 \mathrm{M}\right.$ in $n$-hexane) of ${ }^{n} \mathrm{BuLi}$ and $100 \mathrm{mg}$ $(0.22 \mathrm{mmol})$ of $\left[\left(\mathrm{Et}_{2} \mathrm{~S}\right)_{2} \mathrm{PtCl}_{2}\right]$. Yield: $75 \mathrm{mg}(0.12 \mathrm{mmol}$, $53 \%$ based on $\mathbf{5}$ ).

M.p.: $\left[{ }^{\circ} \mathrm{C}\right] 105$ (dec.). IR (KBr): $\left[\mathrm{cm}^{-1}\right] 2206$ (w) $\left[v_{\mathrm{C}} \equiv \mathrm{C}\right]$. ${ }^{1} \mathrm{H}$ NMR $\left(\mathrm{CDCl}_{3}\right):[\delta] 3.08\left(\mathrm{~s},{ }^{3} J_{\mathrm{PtH}}=36.9 \mathrm{~Hz}, 12 \mathrm{H}\right.$, $\left.\mathrm{NMe} e_{2}\right), 4.00\left(\mathrm{~s},{ }^{3} J_{\mathrm{PtH}}=46.5 \mathrm{~Hz}, 4 \mathrm{H}, \mathrm{CH}_{2} \mathrm{~N}\right), 4.21(\mathrm{pt}$, $\left.J_{\mathrm{HH}}=1.8 \mathrm{~Hz}, 2 \mathrm{H}, \mathrm{C}_{5} H_{4}\right), 4.22\left(\mathrm{~s}, 5 \mathrm{H}, \mathrm{C}_{5} H_{5}\right), 4.46(\mathrm{pt}$, $\left.J_{\mathrm{HH}}=1.8 \mathrm{~Hz}, 2 \mathrm{H}, \mathrm{C}_{5} H_{4}\right), 6.96\left(\mathrm{~s}, 2 \mathrm{H}, \mathrm{C}_{6} H_{2}\right) .{ }^{13} \mathrm{C}\left\{{ }^{1} \mathrm{H}\right\}$ NMR $\left(\mathrm{CDCl}_{3}\right):[\delta] 45.3\left(\mathrm{NCH}_{3}\right), 63.9\left(\mathrm{NCH}_{2}\right), 65.3\left({ }^{i} \mathrm{C} /\right.$ $\left.\mathrm{C}_{5} \mathrm{H}_{4}\right), 68.7\left(\mathrm{CH} / \mathrm{C}_{5} \mathrm{H}_{4}\right), 69.9\left(\mathrm{CH} / \mathrm{C}_{5} \mathrm{H}_{5}\right), 71.3(\mathrm{CH} /$ $\left.\mathrm{C}_{5} \mathrm{H}_{4}\right), 85.7(\mathrm{FcC} \equiv \mathrm{C}), 88.1(\mathrm{FcC} \equiv C), 123.8\left({ }^{i} C / \mathrm{C}_{6} \mathrm{H}_{3}\right)$, $129.1\left(\mathrm{CH} / \mathrm{C}_{6} \mathrm{H}_{3}\right), 130.7\left(\mathrm{CH} / \mathrm{C}_{6} \mathrm{H}_{3}\right), 138.9\left({ }^{i} \mathrm{C} / \mathrm{C}_{6} \mathrm{H}_{3}\right)$. Anal. Calc. for $\mathrm{C}_{24} \mathrm{H}_{27} \mathrm{ClFeN}_{2} \mathrm{Pt}$ (629.86): C, 45.76; H, 4.32; N, 4.45. Found: C, 45.71; H, 4.38; N, 4.41\%.

\subsection{X-ray crystal structure determinations}

X-ray intensities up to a resolution of $(\sin \Theta / \lambda)_{\max }=$ $0.65 \AA^{-1}$ were measured on a Nonius Kappa CCD diffractometer with a rotating anode and a graphite monochromator $(\lambda=0.71073 \AA)$ at a temperature of $150(2) \mathrm{K}$. The structures were solved with automated Patterson methods [25] and refined with SHELXL-97 [26] on $F^{2}$ of all reflections. Non-hydrogen atoms were refined freely with anisotropic displacement parameters. Hydrogen atoms were introduced in geometrically idealised positions and refined with a riding model. Geometry calculations, drawings and checking for higher symmetry were performed with the PLATON package [27].

\subsection{Compound 8}

$\mathrm{C}_{22} \mathrm{H}_{27} \mathrm{ClFeN}_{2} \mathrm{Pt}, F w=605.85$, yellow needle, $0.42 \times$ $0.15 \times 0.06 \mathrm{~mm}^{3}$, monoclinic, $P 2_{1} / \mathrm{c}$ (no. 14 ), $a=14.9051$ (1), $b=16.9068(2), \quad c=21.5612(2) \AA, \quad \beta=129.6807(4)^{\circ}$,
$V=4181.60(9) \AA^{3}, \quad Z=8, \quad D_{x}=1.925 \mathrm{~g} \mathrm{~cm}^{-3} . \quad 65541$ Reflections were measured. An analytical absorption correction was applied (PLATON [28], routine ABST, $\mu=$ $7.51 \mathrm{~mm}^{-1}, 0.14-0.78$ correction range). Nine thousand five hundred and thirty-three reflections were unique $\left(R_{\text {int }}=0.059\right)$. One cyclopentadienyl ring was refined with a disorder model using split positions. 540 Parameters were refined with 154 restraints. $R_{1} / w R_{2}[I \geqslant 2 \sigma(I)]$ : $0.0260 / 0.0583$. $R_{1} / w R_{2}$ [all reflection]: $0.0398 / 0.0631$. $S=1.062$. Residual electron density between -1.38 and $1.40 \mathrm{e} / \AA^{3}$.

\subsection{Compound 13}

$\mathrm{C}_{24} \mathrm{H}_{27} \mathrm{ClFeN}_{2} \mathrm{Pt}, F w=629.87$, red needle, $0.42 \times 0.18 \times$ $0.04 \mathrm{~mm}^{3}$, monoclinic, $P 2_{1} / \mathrm{c}$ (no. 14), $a=12.223(3)$, $b=15.568(2), \quad c=11.9352(12) \AA, \quad \beta=107.610(11)^{\circ}, \quad V=$ 2164.7(7) $\AA^{3}, Z=4, D_{x}=1.933 \mathrm{~g} \mathrm{~cm}^{-3} .22713$ Reflections were measured. An analytical absorption correction was applied (PLATON [28], routine ABST, $\mu=7.26 \mathrm{~mm}^{-1}$, $0.34-0.85$ correction range). 4943 Reflections were unique $\left(R_{\text {int }}=0.06\right)$. The crystal appeared to be non-merohedrally twinned with a twofold rotation about the $a$-axis as twin operation. This twin relationship was taken into account during intensity evaluation [28], data reduction and refinement as HKLF5 twin [29]. 267 Parameters were refined with no restraints. $R_{1} / w R_{2}[I \geqslant 2 \sigma(I)]: 0.0362 / 0.0904 . R_{1} /$ $w R_{2}$ [all reflection]: $0.0462 / 0.0962$. $S=1.073$. Residual electron density between -2.51 and $2.20 \mathrm{e} / \AA^{3}$.

\section{Supplementary material}

CCDC 284746 (complex 8) and 284747 (13) contain the supplementary crystallographic data for this paper. These data can be obtained free of charge from The Cambridge Crystallographic Data Centre via www.ccdc.cam.ac.uk/ data_request/cif.

\section{Acknowledgements}

We are grateful to the Deutsche Forschungsgemeinschaft (DFG) for financial support. The work of M.L. and A.L.S. was supported by the Council for Chemical Sciences of the Netherlands Organization for Scientific Reserach $(\mathrm{CW}-\mathrm{NWO})$.

\section{References}

[1] For example see: (a) J.M. Longmire, X. Zhang, M. Shang, Organometallics 17 (1998) 4374;

(b) P. Dani, M. Albrecht, G.P.M. van Klink, G. van Koten, Organometallics 19 (2000) 4468;

(c) D.E. Bergbreiter, P.L. Osburn, Y. Liu, J. Am. Chem. Soc. 121 (1999) 9531 ;

(d) H.P. Dijkstra, P. Steenwinkel, D.M. Grove, M. Lutz, A.L. Spek, G. van Koten, Angew. Chem., Int. Ed. Engl. 38 (1999) 2186.

[2] For example see: (a) P. Steenwinkel, R.A. Gossage, G. van Koten, Chem. Eur. J. 4 (1998) 759; 
(b) R.A. Gossage, L.A. van de Kuil, G. van Koten, Acc. Chem. Res. 31 (1998) 423;

(c) M. Albrecht, G. van Koten, Angew. Chem., Int. Ed. Engl. 40 (2001) 3750 .

[3] G. Rodríguez, M. Albrecht, J. Schoenmaker, A. Ford, M. Lutz, A.L. Spek, G. van Koten, J. Am. Chem. Soc. 124 (2002) 5127.

[4] (a) S. Back, W. Frosch, I. del Rio, G. van Koten, H. Lang, Inorg. Chem. Commun. 2 (1999) 584;

(b) S. Back, M. Albrecht, A.L. Spek, G. Rheinwald, H. Lang, G. van Koten, Organometallics 20 (2001) 1024.

[5] For examples see: (a) F. Coat, C. Lapinte, Organometallics 15 (1996) 477; (b) D. Astruc, Acc. Chem. Res. 30 (1997) 30, 383;

(c) M. Brady, W. Weng, Y. Zhou, J.W. Seyler, A. Amoroso, A.M. Arif, M. Böhme, G. Frenking, J.A. Gladysz, J. Am. Chem. Soc. 119 (1997) 775.

[6] (a) T. Kaharu, H. Matsubara, S. Takahashi, J. Mater. Chem. 1 (1991) 145;

(b) A. Abe, N. Kimura, S. Tabata, Macromolecules 24 (1991) 6238.

[7] For example see: (a) P.D. Beer, P.A. Gale, G.Z. Chen, Coord. Chem. Rev. 185-186 (1999) 3;

(b) O.B. Sutcliffe, M.R. Bryce, A.S. Batsanov, J. Organomet. Chem. 656 (2002) 211;

(c) P.D. Beer, E.J. Hayes, Coord. Chem. Rev. 240 (2003) 167;

(d) J. Razumiene, A. Vilkanauskyte, V. Gureviciene, V. Laurinavicius, N.V. Roznyatovskaya, Y.V. Ageeva, M.D. Reshetova, A.D. Ryabov, J. Organomet. Chem. 668 (2003) 83;

(e) M.J. Moloto, S.M. Nelana, R.M. Moutloali, I.A. Guzei, J. Darkwa, J. Organomet. Chem. 689 (2003) 387;

(f) W. Keim, W. Bruns, S. Kohlmann, M. Krejcik, Inorg. Chim. Acta. 229 (1995) 143;

(g) M.H. Delville, Inorg. Chim. Acta 281 (1999) 1;

(h) I.R. Farrell, F. Hartl, S. Zalis, T. Mahabiersing, J. Chem. Soc., Dalton Trans. (2000) 4323;

(i) R.D.A. Hudson, J. Organomet. Chem. 637-639 (2001) 47;

(j) I. Fratoddi, C. Battocchio, A. Furlani, P. Mataloni, G. Polzonetti, M.V. Russo, J. Organomet. Chem. 674 (2003) 10;

(k) E.K. Todd, Coord. Chem. Rev. 246 (2003) 3.

[8] For example see: (a) J. Hassan, M. Sévignon, C. Gozzi, E. Schulz, M. Lemaire, Chem. Rev. 102 (2002) 1359;

(b) E. Negishi, L. Anastasia, Chem. Rev. 103 (2003) 1979;

(c) E. Negishi, J. Organomet. Chem. 653 (2002) 34;

(d) K. Sonogashira, J. Organomet. Chem. 653 (2002) 46;

(e) A. Suzuki, J. Organomet. Chem. 653 (2002) 83.

[9] For bis-NCN-pincer functionalised ferrocenes see: (a) S. Köcher, G.P.M. van Klink, G. van Koten, H. Lang, J. Organomet. Chem. 684 (2003) 230;

(b) S. Köcher, G.P.M. van Klink, G. van Koten, H. Lang, Organometallics, submitted for publication.

[10] S. Köcher, G.P.M. van Klink, G. van Koten, H. Lang, submitted for publication.

[11] S. Back, R.A. Gossage, H. Lang, G. van Koten, Eur. J. Inorg. Chem. (2000) 1457.

[12] T. Łuczak, M. Bełtowska-Brzezinska, M. Bron, R. Holze, Vib. Spectr. 15 (1997) 17.
[13] K.R. Thomas, J.T. Lin, Y.S. Wen, J. Organomet. Chem. 575 (1999) 301.

[14] (a) M. Albrecht, R.A. Gossage, U. Frey, A.W. Ehlers, E.J. Baerends, A.E. Merbach, G. van Koten, Inorg. Chem. 40 (2001) 850;

(b) M. Albrecht, M. Schlupp, J. Batgon, G. van Koten, Chem. Commun. (2001) 1874;

(c) M. Albrecht, G. Rodriguez, J. Schoenmaker, G. van Koten, Org. Lett. 22 (2000) 3461;

(d) M. Albrecht, M. Lutz, A.M.M. Schreurs, E.T.H. Lutz, A.L. Speck, G. van Koten, J. Chem. Soc., Dalton Trans. (2000) 3797;

(e) M. Albrecht, M. Lutz, A.L. Spek, G. van Koten, Nature 406 (2000) 970;

(f) M. Albrecht, G. van Koten, Adv. Mater. 11 (1999) 171;

(g) M. Albrecht, R.A. Gossage, A.L. Spek, G. van Koten, Chem. Commun. (1998) 1003.

[15] For example see: (a) Z. Yuan, G. Stringer, R. Jobe, D. Kreller, K. Scott, L. Koch, N.J. Taylor, T.B. Marder, J. Organomet. Chem. 452 (1993) 115;

(b) J.T. Lin, S.S. Sun, J.J. Wu, L. Lee, K.J. Lin, Y.F. Huang, Inorg. Chem. 34 (1995) 2323;

(c) T.J.J. Müller, H.J. Linder, Chem. Ber. 129 (1996) 607;

(d) L.K. Liu, K.Y. Chang, Y.S. Wen, J. Chem. Soc., Dalton Trans. (1998) 741 ;

(e) S. Le Stang, F. Paul, C. Lapinte, Organometallics 19 (2000) 1035; (f) B. Bildstein, Coord. Chem. Rev. 206-207 (2000) 369.

[16] D.R. Kanis, M.A. Ratner, T.J. Marks, J. Am. Chem. Soc. 114 (1992) 10338.

[17] G. Gritzner, J. Kuta, Pure Appl. Chem. 56 (1984) 461.

[18] F.S. Kamounah, J.B. Christensen, J. Chem. Res. (S) (1997) 150.

[19] H.P. Dijkstra, M.D. Meijer, J. Patel, R. Kreiter, G.P.M. van Klink, M. Lutz, A.L. Spek, A.J. Canty, G. van Koten, Organometallics 20 (2001) 3157.

[20] J. Polin, H. Schottenberger, B. Anderson, S.F. Martin, Org. Synth. 73 (1996) 262.

[21] P.K. Byers, A.J. Canty, H. Jin, D. Kruis, B.A. Markies, J. Boersma, G. van Koten, Inorg. Synth. 32 (1998) 162.

[22] M. Albrecht, R.A. Gossage, M. Lutz, A.L. Spek, G. van Koten, Chem. Eur. J. 6 (2000) 1431.

[23] S. Komiya, Synthesis of Organometallic Compounds, Wiley, Winchester, UK, 1997.

[24] (a) B.R. Steele, K. Vrieze, Trans. Met. Chem. 2 (1977) 140; (b) A.J. Canty, J. Patel, B.W. Skelton, A.J. White, J. Organomet. Chem. 599 (2000) 195.

[25] P.T. Beurskens, G. Admiraal, G. Beurskens, W.P. Bosman, S. Garcia-Granda, R.O. Gould, J.M.M. Smits, C. Smykalla, The DIRDIF99 program system, Technical Report of the Crystallography Laboratory, University of Njimegen, The Netherlands, 1999.

[26] G.M. Sheldrick, SHELXL-97, Program for Crystal Structure Refinement, University of Göttingen, 1997.

[27] A.L. Spek, J. Appl. Cryst. 36 (2003) 7.

[28] A.J.M. Duisenberg, L.M.J. Kroon-Batenburg, A.M.M. Schreurs, J. Appl. Cryst. 36 (2003) 220.

[29] R. Herbst-Irmer, G.M. Sheldrick, Acta Crystallogr. B54 (1998) 443. 